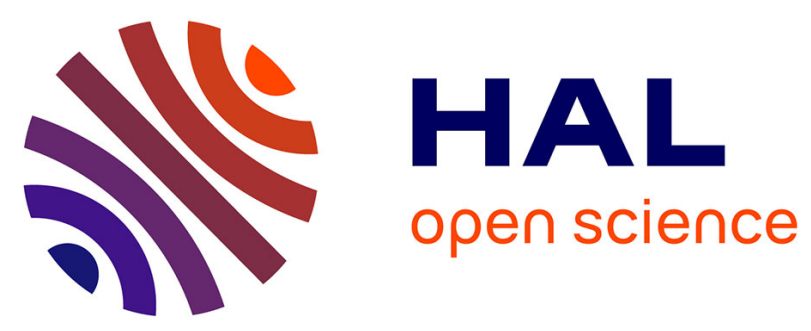

\title{
An Overview of the International H2O Project (IHOP_2002) and Some Preliminary Highlights
}

Tammy Weckwerth, David B. Parsons, Steven E. Koch, James A. Moore, Margaret A. Lemone, Belay B. Demoz, Cyrille Flamant, Bart Geerts, Junhong Wang, Wayne F. Feltz

\section{To cite this version:}

Tammy Weckwerth, David B. Parsons, Steven E. Koch, James A. Moore, Margaret A. Lemone, et al.. An Overview of the International H2O Project (IHOP_2002) and Some Preliminary Highlights. Bulletin of the American Meteorological Society, 2004, 85 (2), pp.253 - 277. 10.1175/BAMS-85-2-253 . hal-01651324

\section{HAL Id: hal-01651324 https://hal.science/hal-01651324}

Submitted on 18 Jul 2020

HAL is a multi-disciplinary open access archive for the deposit and dissemination of scientific research documents, whether they are published or not. The documents may come from teaching and research institutions in France or abroad, or from public or private research centers.
L'archive ouverte pluridisciplinaire HAL, est destinée au dépôt et à la diffusion de documents scientifiques de niveau recherche, publiés ou non, émanant des établissements d'enseignement et de recherche français ou étrangers, des laboratoires publics ou privés. 


\title{
AN OVERVIEW OF THE INTERNATIONAL $\mathrm{H}_{2} \mathrm{O}$ PROJECT (IHOP_2002) AND SOME PRELIMINARY HIGHLIGHTS
}

\author{
by Tammy M. Weckwerth, David B. Parsons, Steven E. Koch, James A. Moore, Margaret A.
} lemone, Belay B. Demoz, Cyrille Flamant, Bart Geerts, Junhong Wang, and Wayne F. Feltz

\section{A plethora of water vapor measuring systems from around the world converged on the U.S. Southern Great Plains to sample the 3D moisture distribution to better understand convective processes.}

A $\mathrm{n}$ accurate prediction of warm-season convective precipitation amounts remains an elusive goal for the atmospheric sciences despite steady advances in the skill of numerical weather prediction models (e.g., Emanuel et al. 1995; Dabberdt and Schlatter 1996). At present, quantitative precipitation forecasting (QPF; please see the appendix for a complete list of acronyms used in this paper) skill also varies seasonally (e.g., Uccellini et al. 1999), with the summer marked by significantly lower threat scores, which indicate lower forecast skill (Fig. 1). An examination of the ratio of winter to summer QPF skill for recent years suggests that seasonal variations in skill score for heavier precipitation amounts may in fact be getting larger. Thus, the small gains in QPF skill mentioned earlier are likely occurring during the

\footnotetext{
AFFiliations: WeCKWERTH, PARSONS-Atmospheric Technology Division, National Center for Atmospheric Research,* Boulder, Colorado; $\mathrm{KoCH}-$ Forecast Systems Laboratory, NOAA Research, Boulder, Colorado; MOORE-Joint Office for Science Support, University Corporation for Atmospheric Research, Boulder, Colorado; LEMONE - Mesoscale and Microscale Meteorology Division, National Center for Atmospheric Research,* Boulder, Colorado; Demoz-Mesoscale Atmospheric Processes Branch, NASA GSFC, Greenbelt, Maryland; FLAMANT-Institute Pierre-Simon Laplace/Service d'Aéronomie, Centre National de la Recherche Scientifique, Université Pierre et Marie Curie, Paris, France; GeerTsDepartment of Atmospheric Science, University of Wyoming, Laramie, Wyoming; WANG-Atmospheric Technology Division,
}

National Center for Atmospheric Research,* Boulder, Colorado; FELTZ-Cooperative Institute for Meteorological Satellite Studies, Space Science and Engineering Center, University of WisconsinMadison, Madison, Wisconsin

*The National Center for Atmospheric Research is sponsored by the National Science Foundation.

CORRESPONDING AUTHOR: Dr. Tammy Weckwerth, NCAR/ ATD, P.O. Box 3000, Boulder, CO 80307-3000

E-mail: tammy@ucar.edu

DOI: 10.1175/BAMS-85-2-253

In final form 3 October 2003

(C)2004 American Meteorological Society 


\section{4-Hour 1.00" QPF Verification}

\section{Day 1 Forecast --- HPC vs. NGM}

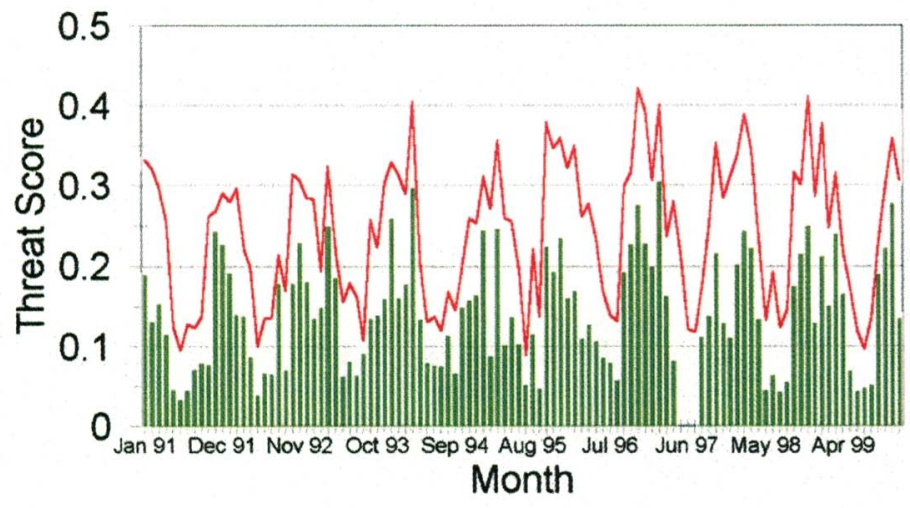

Nested Grid Model — HPC Forecasters

FIG. I. Monthly threat scores for quantitative precipitation forecasts at the I-in. or greater threshold for the period from Jan I99I to Dec 1999. Threat scores are plotted for the NGM (green histogram) and for the HPC forecaster predictions (red line) for the 24-h period. Figure courtesy of D. Reynolds of NOAA/NCEP/HPC (from Uccellini et al. 1999. accurate estimates of water vapor within and just above the boundary layer (Crook 1996). Such a relationship is expected because the prediction of convective precipitation is strongly dependent on the vertical profile of buoyancy within clouds, which is itself strongly dependent upon the magnitude of water vapor within the boundary layer. Once convection develops, the vertical profile of water vapor is of first-order importance in the prediction of precipitation rates since water vapor is directly involved in determining various thermodynamic and microphysical processes.

One necessary condition for an accurate prediction of convective rainfall is a good forecast of where and when convection will initially develop. Currently, the prediction and understanding of convection initiation processes, as well as the subsequent intensity, areal coverage, winter season when the skill is already significantly higher. The low skill in forecasting the timing, location, and intensity of convective rainfall and the relative lack of progress for warm-season rainfall forecasting are particularly worrisome since significant weather hazards occur in the warm season. In the United States, for example, flash floods are responsible for more deaths than hurricanes, tornadoes, wind storms, or lightning (e.g., Doswell et al. 1996), and flash floods account for billions of dollars in property damage each year.

Some of this lack of skill in summer QPF for heavy rainfall is surely related to the fact that current operational mesoscale prediction models must parameterize convection as a subgrid-scale (i.e., smaller than $10 \mathrm{~km}$ ) process. Early convective storms, in particular, are only a few kilometers in size, and thus the models do not fully represent their dynamical structure and microphysical processes. Evidence suggests that an accurate characterization of water vapor in the lower atmosphere is a necessary condition for quantitative prediction of precipitation in models with parameterized convection (e.g., Perkey 1976; Mills 1983; Mills and Davidson 1987; Mailhot et al. 1989; Bell and Hammon 1989; Emanuel et al. 1995; Dabberdt and Schlatter 1996; Koch et al. 1997). Predicting the initiation of convection in cloudresolving models can also be highly dependent on very and distribution of convective rainfall, are impeded by inaccurate and incomplete water vapor measurements (e.g., National Research Council 1998). Figure 2

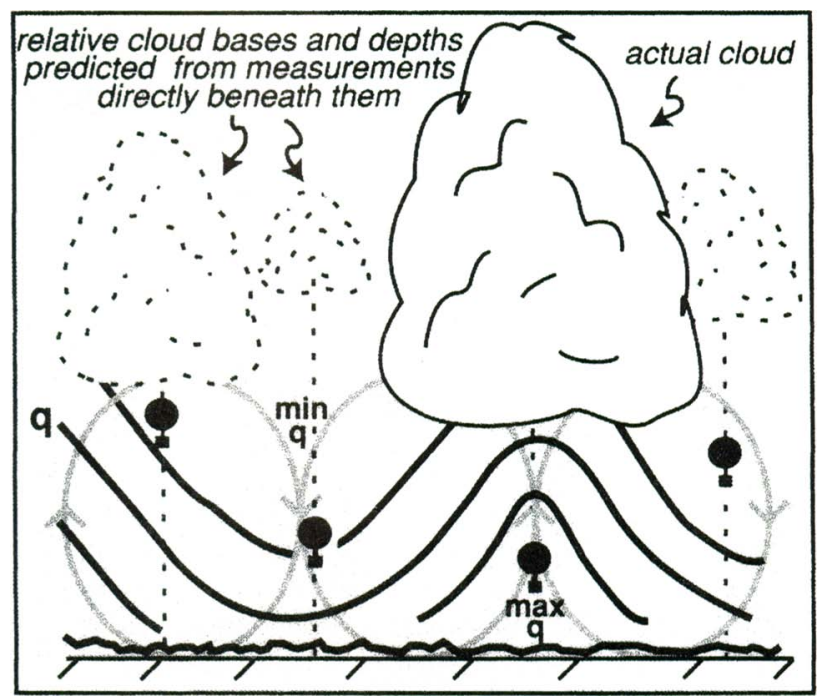

FIG. 2. Schematic diagram showing mesoscale moisture variability (black contours) associated with horizontal convective rolls (gray circulations). Actual cloud base and depth are shown by the large solid cloud. Smaller dashed clouds represent relative cloud bases and depths expected if stability parameters were estimated from CBL moisture values directly beneath those clouds (from Weckwerth et al. 1996). 
shows that in the presence of horizontal convective rolls, for example, water vapor is undersampled in space and time (Weckwerth et al. 1996) because existing observational techniques for mapping the threedimensional distribution of water vapor are lacking. Radiosondes, the traditional means of obtaining water vapor measurements, are insufficient because they provide vertical profile information at widely distributed locations often separated by hundreds of kilometers and are typically only available twice a day and have significant errors and biases (e.g., Soden and Lanzante 1996; Guichard et al. 2000; Wang et al. 2002; Revercomb et al. 2003). Additionally, there is a general absence of operational ground-based water vapor remote sensing systems, and many satellite techniques cannot obtain high-vertical-resolution water vapor measurements with high accuracy in the lower troposphere. When horizontal moisture variability and realistic mesoscale details in the relative humidity and surface moisture availability are included, pronounced improvements in forecast skill for convective events can occur (e.g., Koch et al. 1997; Parsons et al. 2000; Weckwer th 2000). Thus, while water vapor measurements are critically linked to convective processes, measurements are simply not available to derive high quality initial conditions for the next generation of numerical weather prediction models or to provide guidance for forecasters seeking to nowcast convective development and evolution. A community workshop on obtaining improved water vapor measurements concluded that better understanding of convective processes may require spatial and temporal resolution of $100 \mathrm{~m}$ horizontally and vertically and 10 min, respectively (Weckwerth et al. 1999). Adequate means for measuring water vapor at such spatial and temporal scales are only now beginning to emerge.

The researchers associated with IHOP_2002 are addressing these general issues through four coordinated research components: (i) the QPF research component is seeking to determine the degree of improvement in forecast skill that occurs through improved characterization of the water vapor field, (ii) the convection initiation (CI) research component is seeking to better understand and predict the processes that determine where and when convection first forms, (iii) the atmospheric boundary layer $(\mathrm{ABL})$ processes research component is seeking to improve understanding of the relationship between atmospheric water vapor and surface and boundary layer processes and their impact on CI, and (iv) the instrumentation research component is seeking to determine the future optimal mix of operational water vapor measurement strategies to better predict warmseason rainfall. This group is also working toward better quantification of measurement accuracy, precision, and performance limitations.

This field project was unique and challenging in several ways, many of which will be highlighted in this paper. Some of the outstanding accomplishments of the field phase of IHOP_2002 are

- collection of three-dimensional time-varying measurements of the water vapor distribution at meshing scales,

- coordination of more than 60 IHOP_2002-specific instruments in the field phase,

- participation of numerous instruments in their first deployment and multiple collocation of complementary instrumentation for the first time,

- realization of the utility of numerous new sensors, especially reference radiosonde and radar refractivity, and

- surprising observations of the ubiquity of bores, low-level gravity waves that may affect the nocturnal initiation and maintenance of convective systems.

These accomplishments and others are presented in this paper. The next section describes the experimental design and the impressive combination of instruments and numerical models involved followed by a discussion of many of the unique and challenging aspects of IHOP_2002. Some of the preliminary scientific results are then shown followed by a summary.

\section{IHOP_2002 EXPERIMENTAL DESIGN, INSTRUMENTATION, AND MODELS. The} IHOP_2002 field campaign was largely conceived as a result of the 1998 Water Vapor Workshop. Around the same time, the convection initiation scientists were planning the Thunderstorm Initiation Mobile Experiment (TIMEx) and realized that the campaign could not be successful without improved water vapor measurements. Thus these two groups combined to plan IHOP_2002. The large and complex experiment took over 4 yr to secure sufficient funds and properly plan.

The IHOP_2002 project took place in the Southern Great Plains (SGP) of the United States from 13 May to 25 June 2002. The SGP was chosen for IHOP_2002 for several reasons: 1) the extensive array of preexisting operational and experimental instruments, 2) both convection initiation and active convection occurring over the region, 3 ) large hori- 
zontal gradients in water vapor, and 4) a strong eastwest gradient in rainfall over this area. The experimental strategy took advantage of existing observing systems in this region, including the operational Weather Surveillance Radar-1988 Doppler (WSR88D) units, operational surface meteorological sites including Oklahoma and other state mesonets, the NWS soundings, the Atmospheric Radiation Measurement (ARM) facilities with five atmospheric emitted radiance interferometer (AERI) sites; the National Oceanic and Atmospheric Administration (NOAA) Wind Profiler Network, and the Argonne Boundary Layer Experiments (ABLE). The Oklahoma Mesonet measurements were critical to the ABL component, in particular, the 30-min-interval soil moisture observations taken from 101 locations across Oklahoma. A subset of 10 mesonet stations, designated supersites, included instrumentation to directly compute sensible and latent heat fluxes ( $\mathrm{SH}$ and $\mathrm{LH}$, respectively) using the eddy correlation approach (e.g., Basara and Crawford 2002). The rawinsonde network included soundings launched continuously at 3-h intervals from five ARM facilities during a 3-week ARM intensive observing period (IOP; see Table 1) and special soundings launched at 3-h intervals from select $\mathrm{Na}$ tional Weather Service (NWS) sites upon request. An overview map of the IHOP_2002 regional sounding domain with other preexisting and IHOP_2002specific instrumentation is shown in Fig. 3.

IHOP_2002-specific fixed and mobile groundbased sensors supplemented the operational measurement sites. Table 1 lists all of the IHOP_2002-

TABLE I. IHOP_2002-specific instruments, including their location or mode of operation, supporting institution, dates of participation, number of operational days ("cont." implies continuous 24/7 operations), and relevant references. Please see appendix for list of acronyms.

\begin{tabular}{|c|c|c|c|c|c|}
\hline \multicolumn{6}{|c|}{ IHOP_2002-Specific instruments } \\
\hline Instrument & $\begin{array}{l}\text { Platform/ } \\
\text { location }\end{array}$ & Institution & IHOP dates & $\begin{array}{c}\text { Days of } \\
\text { operation }\end{array}$ & Reference \\
\hline \multicolumn{6}{|c|}{ Water/vapor DIALS } \\
\hline LASE & NASA DC-8 & NASA Langley & 24 May-14 Jun & 7 & Browell et al. (1997) \\
\hline DLR DIAL & DLR Falcon & DLR & 17 May-15 Jun & 18 & Poberaj et al. (2002) \\
\hline Leandre II & NRL P-3 & CNRS & 19 May-25 Jun & 24 & Bruneau et al. (200I) \\
\hline CODI & ARM CART CF & NOAA/ETL & 21 May-2I Jun & 8 & Machol et al. (2004)* \\
\hline \multicolumn{6}{|c|}{ Interferometers } \\
\hline NAST-I & Proteus & NASA Langley & 30 May-12 Jun & 7 & Zhou et al. (2002) \\
\hline S-HIS & NASA DC-8 & NASA & 24 May-14 Jun & 7 & Revercomb et al. (1998) \\
\hline AERIBAGO & Profiling site & $\begin{array}{l}\text { University of } \\
\text { Wisconsin- } \\
\text { Madison }\end{array}$ & 13 May-25 Jun & Cont. & Feltz et al. (2003) \\
\hline \multicolumn{6}{|l|}{ GPS receivers } \\
\hline 7 GPS & $\begin{array}{l}\text { Around ARM/ } \\
\text { CF }\end{array}$ & $\begin{array}{l}\text { Meteo-Francel } \\
\text { CNRS }\end{array}$ & 13 May-25 Jun & Cont. & Businger et al. (1996) \\
\hline GPS & SRL & NASA & 14 May-23 Jun & Cont. & Businger et al. (1996) \\
\hline Mobile GPS & Mobile & $\begin{array}{l}\text { Purdue } \\
\text { University }\end{array}$ & I Jun-14 Jun & 14 & Dodson et al. (2001) \\
\hline \multicolumn{6}{|l|}{ Lidars } \\
\hline SRL & Profiling site & NASA & 19 May-21 Jun & 21 & Whiteman and Melfi (1999) \\
\hline HRDL & DLR Falcon & NOAA/ETL & 17 May-15 Jun & 18 & Grund et al. (200I) \\
\hline HARLIE & Profiling site & NASA & 15 May-24 Jun & 21 & Schwemmer et al. (1998) \\
\hline GLOW & Profiling site & NASA & 13 May-25 Jun & 21 & Gentry et al. (2000) \\
\hline
\end{tabular}

*Manuscript submitted to Appl. Opt. 
TABLE I. (continued)

\begin{tabular}{|c|c|c|c|c|c|}
\hline \multicolumn{6}{|c|}{ IHOP_2002_Specific instruments } \\
\hline Instrument & $\begin{array}{l}\text { Platform/ } \\
\text { location }\end{array}$ & Institution & IHOP dates & $\begin{array}{l}\text { Days of } \\
\text { operation }\end{array}$ & Reference \\
\hline $\begin{array}{l}\text { Radiometer } \\
\text { DRI MMR }\end{array}$ & Mobile & DRI & 13 May-25 Jun & 22 & Huggins (1995) \\
\hline Radars & & & & & \\
\hline ELDORA & NRL P-3 & NCAR & 19 May-25 Jun & 24 & Hildebrand et al. (1996) \\
\hline WCR & UWKA & $\begin{array}{l}\text { University of } \\
\text { Wyoming }\end{array}$ & 13 May-25 Jun & 28 & Pazmany et al. (1994) \\
\hline 2 DOWs & Mobile & OU/NCAR & 13 May-25 Jun & 27 & Wurman (2001) \\
\hline I SMART-R & Mobile & NSSL/TAMU & 13 May-18 Jun & 12 & Biggerstaff and Guynes (2000) \\
\hline S-Pol & $\begin{array}{l}\text { Oklahoma } \\
\text { panhandle }\end{array}$ & NCAR & 13 May-25 Jun & Cont. & Lutz et al. (1995) \\
\hline FM-CW & Profiling site & UMass & 13 May-14 Jun & Cont. & Ince et al. (2003) \\
\hline $\begin{array}{l}\text { UMass millimeter } \\
\text { wave }\end{array}$ & Mobile & UMass/OU & 22 May-10 Jun & 4 & $\begin{array}{l}\text { Bluestein and } \\
\text { Pazmany (2000) }\end{array}$ \\
\hline X-Pol & Mobile & UConn & 16 May-19 Jun & 23 & Wurman (200I) \\
\hline $\begin{array}{l}\text { Profilers } \\
\text { ISS/MAPR/sodar } \\
\text { MIPS/sodar }\end{array}$ & $\begin{array}{l}\text { Profiling Site } \\
\text { Mobile }\end{array}$ & $\begin{array}{l}\text { NCAR } \\
\text { UA-Huntsville }\end{array}$ & $\begin{array}{l}13 \text { May-25 Jun } \\
13 \text { May-25 Jun }\end{array}$ & $\begin{array}{c}\text { Cont. } \\
28\end{array}$ & $\begin{array}{l}\text { Cohn et al. (200I) } \\
\text { Knupp et al. (2000) }\end{array}$ \\
\hline $\begin{array}{l}\text { Surface stations } \\
9 \text { ISFF }\end{array}$ & $\begin{array}{l}\text { Oklahoma/ } \\
\text { Kansas }\end{array}$ & NCAR & 13 May-25 Jun & Cont. & Chen et al. (2003) \\
\hline CU flux station & $\begin{array}{l}\text { Oklahoma } \\
\text { panhandle }\end{array}$ & $\mathrm{CU}$ & 13 May-25 Jun & Cont. & none \\
\hline 9 Mobile mesonets & Mobile & NSSL/TAMU & 13 May-25 Jun & 18 & Straka et al. (1996) \\
\hline 5 surface stations & $\begin{array}{l}\text { Surrounding } \\
\text { S-Pol }\end{array}$ & NCAR & 13 May-25 Jun & Cont. & none \\
\hline Soundings & & & & & \\
\hline Dropsondes & $\begin{array}{l}\text { Learjet and } \\
\text { Falcon }\end{array}$ & $\begin{array}{l}\text { NCAR and } \\
\text { DLR }\end{array}$ & 13 May-25 Jun & 20 and 18 & Hock and Franklin (1999) \\
\hline Radiosondes & ISS/profiling site & NCAR & 13 May-25 Jun & 44 & Parsons et al. (1994) \\
\hline 2 MGLASS & Mobile & NCAR & 13 May-25 Jun & 21 & Bluestein (1993) \\
\hline MCLASS & Mobile & NSSL/TAMU & 13 May-25 Jun & 14 & Frederickson (1993) \\
\hline ARM supplementals & ARM/CART & ARM & 25 May-15 Jun & 21 & Lesht (1995) \\
\hline NWS supplementals & $\begin{array}{l}\text { ABQ, AMA, DNR, } \\
\text { DDC, FWD, MAF, } \\
\text { OUN, LBF, SHV, } \\
\text { TOP }\end{array}$ & NWS & 13 May-25 Jun & 19 & Golden et al. (1986) \\
\hline Reference sonde & Profiling site/DDC & NCAR & 28 May-16 Jun & 16 & Wang et al. (2003) \\
\hline TAOS & Profiling site & NCAR & 12 Jun-25 Jun & 4 & $\begin{array}{l}\text { http://www.atd.ucar.edu/rtf/ } \\
\text { facilities/taos/taos.pdf }\end{array}$ \\
\hline
\end{tabular}




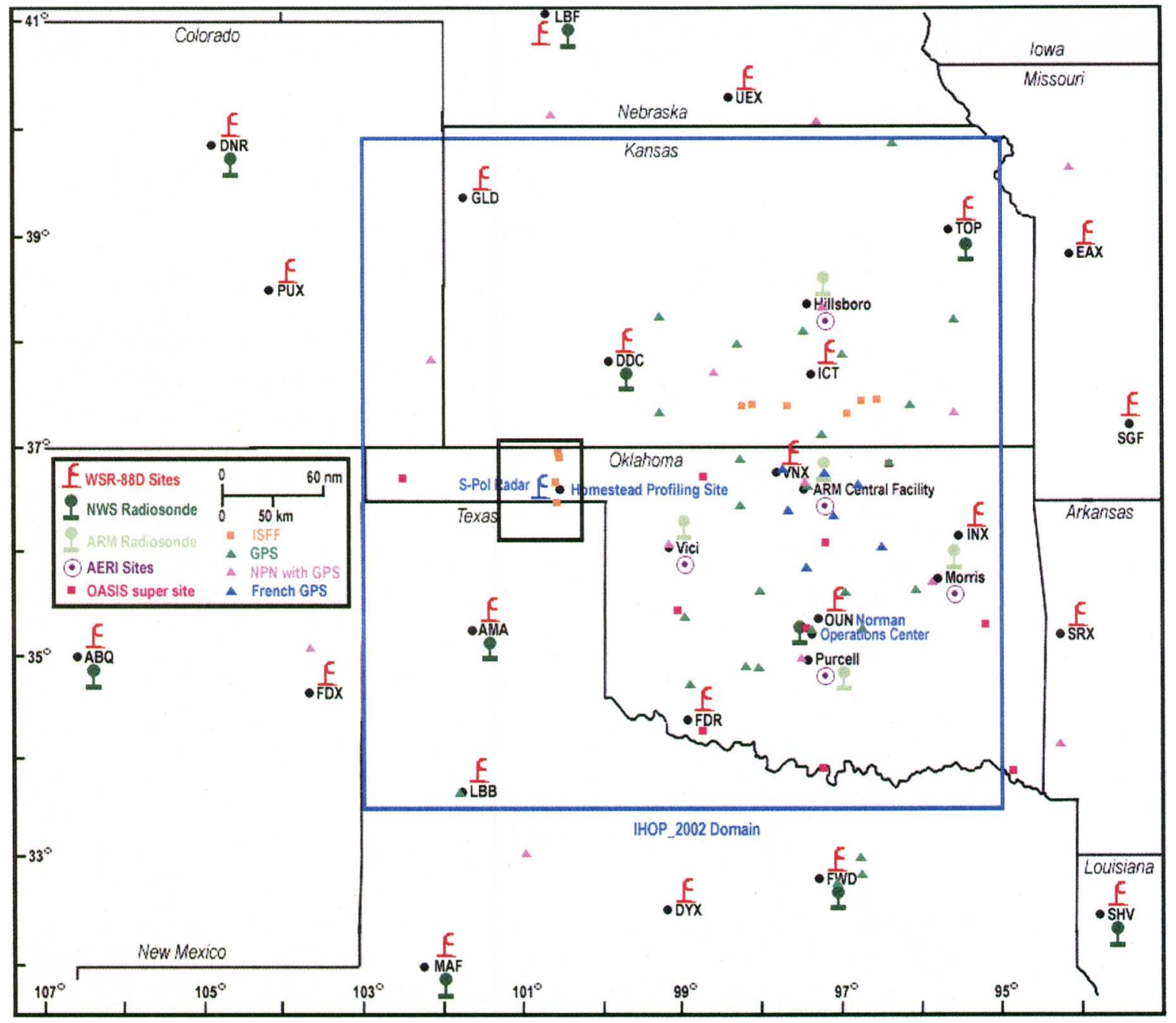

FIG. 3. Overview map of IHOP_2002 domain and surroundings. Shown are the WSR-88D radar sites (red radar symbols), NWS sounding sites (dark green balloons), NOAA Profiler Network (NPN) sites (purple triangles), ARM sounding sites (light green balloons), AERI locations (circle with an inner dot), GPS receivers (blue and green triangles), and flux-measuring surface sites (magenta and orange squares). IHOP_2002 domain and Norman operations center are shown. S-Pol radar and nearby Homestead Profiling Site are shown in the Oklahoma panhandle. Low-level UWKA flight tracks were flown over the three sets of ISFF stations (orange squares) in the western, central, and eastern portions of the IHOP_2002 domain. Region within black box is shown in Fig. 4. Please see the appendix for list of acronyms.

specific instruments and their references. Within the regional array of Fig. 3, Fig. 4 shows a concentration of IHOP_2002 research instruments, including the National Center for Atmospheric Research (NCAR) S-band dual-polarization Doppler radar (SPol); numerous surface stations, some of which measure surface fluxes; a tethersonde; a multitude of instruments based at the Homestead Profiling Site; and numerous mobile instruments based in Liberal, Kansas. The mobile instrumentation was a key element in the CI studies, with these instrument platforms deployed to regions where convective activity was likely to occur.
In addition to the ground-based sites, six research aircraft participated in IHOP_2002, all but one with remote sensing instrumentation (Table 1). The Naval Research Laboratory (NRL) P-3 had a unique combination of sensors, including NCAR's airborne Electra Doppler Radar (ELDORA) and Leandre II [Centre National de la Recherche Scientifique (CNRS)/France's airborne water vapor differential absorption lidar (DIAL)]. Leandre II was pointed downward for ABL and QPF missions and was operational in a horizontal-pointing mode during $\mathrm{CI}$ missions. The National Aeronautics and Space Administration (NASA) DC-8 with an upward- and 


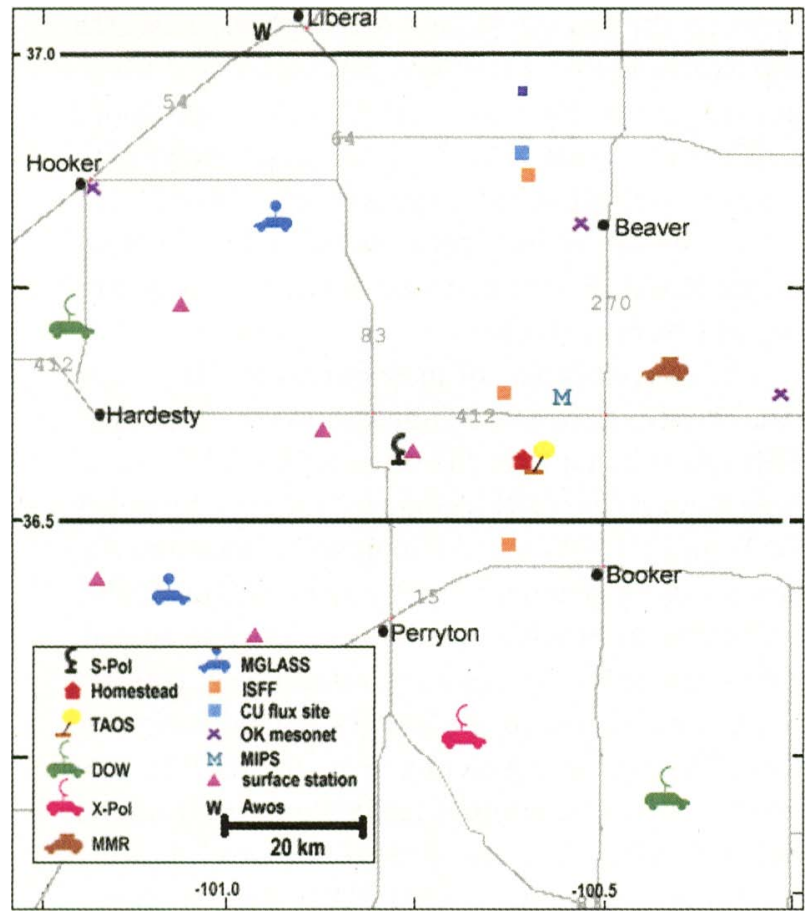

FIG. 4. Region within black box of Fig. 3 centered on S-Pol showing the locations of many operational and IHOP_2002-specific instruments commonly operating in the Oklahoma panhandle.

downward-pointing Lidar Atmospheric Sensing Experiment (LASE) water vapor DIAL and Scanning High-Resolution Interferometer Sounder (S-HIS) was used to map the large-scale moisture distribution. The Deutsche Luft und Raumfahrt (DLR) Falcon had a downward-pointing water vapor DIAL also mapping the water vapor fields. Additionally, the Falcon launched numerous dropsondes and housed NOAA's high-resolution Doppler lidar (HRDL), providing high-resolution wind measurements. The Flight International Lear jet was utilized as a dedicated dropsonde aircraft for IHOP_2002. The University of Wyoming King Air (UWKA) was a critical platform for both $\mathrm{ABL}$ and $\mathrm{CI}$ missions. The UWKA housed the 94-GHz Wyoming Cloud Radar (WCR), which obtained high-resolution Doppler and backscatter measurements of boundary layer motions in clear air and within clouds. The high-flying Proteus (up to $15.2 \mathrm{~km}$ MSL) with its National Polar-orbiting Environmental Satellite System (NPOESS) Aircraft Sounder Testbed (NAST-I) sensor was flown for several missions, and data collected will be extensively utilized for satellite design and verification studies.

IHOP_2002 was also the focus of the annual Spring Program real-time research and forecast verification effort (Janish et al. 2002) held in Norman, Oklahoma. Participation included the Storm Prediction Center
(SPC), National Severe Storms Laboratory (NSSL), National Centers for Environmental Prediction/Experimental Modeling Center (NCEP/EMC), Forecast Systems Laboratory (FSL), the Norman NWS Forecast Office, the NWS Warning Decision Training Branch, and Iowa State University. Spring Program personnel provided forecast support in terms of Day 1 (i.e., the current day) and Day 2 (i.e., the next day) probabilistic forecasts of the locations of convection initiation, Day 2 forecasts of low-level jet activity and the occurrence of nocturnal mesoscale convective systems, as well as a subjective verification of Day 1 forecasts and the forecast utility of nonstandard IHOP_2002 observations and experimental numerical weather prediction models run by FSL. These forecasts provided valuable guidance for planning. Once special instruments were deployed, however, the forecast responsibilities shifted toward a team of SPC and FSL nowcasters associated with the experiment. Various diagnostic fields from the FSL model forecasts, as well as the operational models and observations, were displayed at the IHOP_2002 operations center and also at SPC using the FSL weather product analysis/display system (FX-Net), a system developed at FSL that provides the basic capabilities of an Advanced Weather Interactive Processing System (AWIPS) workstation. This system proved invaluable in providing forecasts for use in strategic planning. Several numerical models at various resolutions were run in real time during IHOP_2002, many of which were utilized in support of the Spring ProgramIHOP_2002 forecast effort (Table 2).

\section{UNIQUE AND CHALLENGING ASPECTS.}

IHOP_2002 presented numerous challenges in both instrumentation and logistics. Not only was this the first time that a Doppler radar and water vapor DIAL were flown on the same aircraft (i.e., NRL P-3), it was also the first time a water vapor DIAL was flown in a horizontal-pointing mode. This allowed for the collocated observations of the clear-air wind field from ELDORA in the context of the preconvective moisture field from Leandre II. The operation of non-eyesafe Leandre II in horizontal mode required the support of an aircraft-proximity radar and careful flight planning. The small proximity radar was designed to ignore ground clutter during typical low-level CI flights (300 m AGL) but still detect aircraft within $5 \mathrm{~km}$ of the NRL P-3. When the radar detected other aircraft within this zone, Leandre II was automatically disabled. Another first for IHOP_2002 was the combination of a water vapor DIAL and Doppler lidar (i.e., HRDL) on the same aircraft (i.e., DLR Falcon). 
TABLE 2. Numerical prediction models run in realtime during IHOP_2002 and their resolutions.

\begin{tabular}{|l|l|}
\hline Model & Resolution \\
\hline Eta & $12 \mathrm{~km}$ \\
\hline Window Eta & $8 \mathrm{~km}$ \\
\hline Experimental Eta-Kain-Fritsch (KF) & $22 \mathrm{~km}$ \\
\hline Operational RUC & $20 \mathrm{~km}$ \\
\hline $\begin{array}{l}\text { Operational RUC run by FSL } \\
\text { MM5 initialized with LAPS; run with } \\
\text { "hot start" diabatic initialization } \\
\text { procedure to improve the precipitation } \\
\text { "spinup" in the first few hours of the } \\
\text { forecast period, useful for nowcasting } \\
\text { purposes }\end{array}$ & $10 \mathrm{~km}$ \\
\hline $\begin{array}{l}\text { WRF at NCAR (Eulerian mass } \\
\text { coordinate version) }\end{array}$ & 22 and $10 \mathrm{~km}$ \\
\hline $\begin{array}{l}\text { WRF-KF at NSSL } \\
\text { Advanced Regional Prediction } \\
\text { System (ARPS) }\end{array}$ & $20 \mathrm{~km}$ \\
\hline \begin{tabular}{l} 
MM5 with AERI data assimilation \\
\hline
\end{tabular} & 27,9 , and $3 \mathrm{~km}$ \\
\hline
\end{tabular}

The operation of both in downward-pointing mode (HRDL had the added capability of being pointed $20^{\circ}$ off nadir) enabled the combined measurements of vertical profiles of water vapor and vertical air motion, thereby providing moisture flux divergence. In the past, HRDL had been used as a ground-based or ship-based system; thus IHOP_2002 also marked the first time it was flown on an airborne platform. The WCR was upgraded for IHOP_2002 to add the capability of vertical-plane dual-Doppler measurements beneath the UWKA.

Many of the ground-based sensors made their debut during IHOP_2002, including the NCAR reference radiosonde, which provided intercomparisons between a reference moisture sensor and the commonly used research and operational soundings. The NOAA/Environmental Technology Laboratory compact DIAL (CODI) participated in its first field campaign. It was located at the ARM Cloud and Radiation testbed (CART) central facility for validation and intercomparison measurements. The NSSL field coordination (FC) vehicle was substantially upgraded for IHOP_2002. The FC vehicle housed computers and communication equipment that allowed the principal investigators to direct the mobile mesonets and mobile sounding systems, retrieve their data, overlay them on the Shared Mobile Atmospheric Research and Teaching Radar (SMART-R) display, and transmit the images back to the IHOP_2002 operations center every $5 \mathrm{~min}$. This system also provided critical communications with two of the CI aircraft. The University of Connecticut's Mobile X-Band Polarimetric Radar (X-Pol) operated nearly flawlessly during its first field campaign.

The concentration of instruments at the Homestead Profiling Site was a unique aspect of the project. This was the first time the three NASA lidars, scanning Raman lidar (SRL), Goddard Lidar Observatory for Winds (GLOW), and Holographic Airborne Rotating Lidar Instrument Experiment (HARLIE), were collocated to provide information on water vapor, winds, and aerosol backscatter, respectively. The profiling site also hosted the Integrated Sounding System (ISS)/Multiple Antenna Profiler (MAPR), mobile atmospheric emitted radiance interferometer (AERIBAGO), and the Frequency ModulationContinuous Wave Radar (FM-CW). The mobile integrated profiling system (MIPS) often operated at the profiling site when not participating in mobile operations. The tethersonde instrument, Tethered Atmospheric Observing System (TAOS), was deployed $0.5 \mathrm{~km}$ away to minimize the interference with MAPR. Many instrument intercomparisons are now underway between these ground-based measurements, aircraft overflight data, and satellite retrievals.

Another unique and ground-breaking data collection effort was launched by the ABL group. They used 10 surface flux stations across the climatological 100th-meridian precipitation gradient to fully characterize the vegetated surface and its variability. Emphasis was placed on linking the characterization to airborne and satellite remote sensors. Comprehensive measurements of soil moisture and vegetation characteristics were taken throughout the experiment (Chen et al. 2003) to enable definitive testing and development of land surface models.

The FSL models ingested Geostationary Operational Environmental Satellite (GOES) sounder estimates of total precipitable water (TPW) and cloudtop pressure (CTP), GPS TPW, Oklahoma Mesonet, and the special NWS sounding data. GOES-11 CTP and TPW products were produced at an unprecedented 30-min interval and ingested into the experimental FSL models upon receiving approval from National Environmental Satellite, Data, and Information Service (NESDIS) management to activate GOES-11 in support of IHOP_2002 field operations from 3 to 21 June 2002. The GOES-11 5-min visible 
satellite imagery was successfully used to provide realtime observations for CI nowcasting. This real-time, high-resolution, rapid-scan imagery allowed for detailed tracking of boundaries and cumulus cloud development. In addition, FSL developed the ability to assimilate WSR-88D level II reflectivity and radial velocity data from the 11 Collaborative Radar Acquisition Field Test (CRAFT) radar sites (Droegemeier et al. 2002) into the Local Analysis and Prediction System (LAPS)/fifth-generation Pennsylvania State University-NCAR Mesoscale Model (MM5)demonstrating that broadband data from multiple radars could effectively be used for diabatic initialization of this mesoscale modeling system. The CRAFT data stream was also tapped by NCAR to create a realtime radar composite field using the radars from the central United States in addition to S-Pol. This composite radar display was extremely valuable for nowcasting and directing aircraft and ground-based mobile systems during operations.

The combined observations of more than 60 data collection instruments and facilities summarized in Table 1 required an extraordinary level of operations coordination. The communications network to support IHOP_2002 consisted of all forms of connectivity from radios to cell phones to high-bandwidth data lines to satellite voice and data links. The IHOP_2002 Project Office and participating scientists spent a considerable amount of time designing and implementing a network to minimize single points of failure while providing all participants information required to conduct a well-coordinated complex measurement strategy. The combined efforts of several groups including NSSL (hosted the main IHOP_2002 operations center), SPC (provided special forecast services and products), NOAA/FSL (provided special software, numerical models, and forecast support), NCAR/Atmospheric Technology Division (provided data links and real-time integrated weather, radar, and aircraft position information), and University Corporation for Atmospheric Research (UCAR)/Joint Office for Science Support (JOSS) (provided the IHOP_2002 Field Catalog and operations support services) resulted in a very successful field operations coordination. IHOP_2002 was able to provide positive control and safe operations for as many as six research aircraft conducting highly complex flight strategies in close coordination with ground facilities. Predeployment of mobile ground facilities to regions of interest permitted data collection throughout the lifetime of conditions of interest.

Important lessons learned and highlights from the IHOP_2002 operations include the following:
- Excluding several instruments that provided continuous data collection during the 44-day field season, there were 38 days on which special deployment of ground or airborne facilities occurred with a total of 49 missions (Table 3 ). This was only possible through an extraordinary level of cooperation and compromise among the scientists and dedicated attention to detail from the operations support staff. Please see the complete summary of operations in the IHOP_2002 Field Catalog online at www.joss.ucar.edu/ihop/catalog/.

- It is possible to conduct multiple aircraft operations in heavily used military- and civilian-controlled airspace with proper advanced planning and in-field coordination with appropriate military and civilian air traffic authorities.

- It is critical to have real-time flight track information and reliable direct aircraft communication when conducting high-resolution measurements in the vicinity of developing convection.

- The coordination of mission planning with scientists at remote sites requires reliable and equivalent data and information and voice communications at convenient locations.

- It is essential to have nowcasting support in the operations center during developing convective situations so that direct communication is possible between aircraft coordinators, nowcasters, and airborne mission scientists.

IHOP_2002 staff worked from early in the planning phase to develop and implement a comprehensive data management strategy. JOSS, in close collaboration with ATD, has developed a data archive for all IHOP_2002 related datasets. A data policy, data access, and format and documentation guidelines were all put in place with emphasis on the need to share a variety of data quickly and easily to answer critical science questions. Special data collection of operational data from NWS, ARM, and regional mesonetwork sources were all collected during the field season. Further details about IHOP data management and access to all project datasets may be found online at www.joss.ucar.edu/ihop/dm/.

\section{HIGHLIGHTS OF PRELIMINARY FINDINGS.}

QPF. The overall objective of IHOP_2002 is to ascertain whether or not improved characterization of the four-dimensional distribution of water vapor will result in significant, detectable improvements in warmseason QPF skill. The Hydrometeorological Prediction Center (HPC) evaluated 6-hourly forecasts of precipitation from the 0000 UTC runs of the Rapid 
TABLE 3. IHOP_2002 mission summary table listing the various missions, the number of times they were called, and the instruments that most likely participated. Please see http://www.joss.ucar.edu/ ihop/catalog/missions.html for a more detailed list of missions performed and the appendix for list of acronyms.

\begin{tabular}{|c|c|c|}
\hline Mission type & $\begin{array}{l}\text { Number of } \\
\text { missions }\end{array}$ & Typical instruments \\
\hline $\mathrm{Cl}$ & 18 & $\begin{array}{l}\text { UWKA with WCR, P-3 with horizontal L2 and ELDORA, Lear jet drop- } \\
\text { sondes, Falcon with DIAL, DC-8 with LASE and S-HIS, Proteus with NAST-I, } \\
\text { DOWs, SMART-R, S-Pol, X-Pol, ISS/MAPR, ISS radiosondes, NWS radio- } \\
\text { sondes, MIPS, FC, MMs, ISFFs, MMR, SRL, GLOW, HARLIE, MGLASS, } \\
\text { MCLASS, FM-CW, AERIBAGO }\end{array}$ \\
\hline $\begin{array}{l}\text { Boundary layer } \\
\text { heterogeneity } \\
\text { (BLH) }\end{array}$ & 15 & $\begin{array}{l}\text { UWKA with WCR, P-3 with downward L2 and ELDORA, Lear jet } \\
\text { dropsondes, Falcon with DIAL, HRDL and dropsondes, ISFFs, S-Pol, } \\
\text { ISS/MAPR, ISS radiosondes, DOWs, X-Pol, MIPS, FM-CW, AERIBAGO }\end{array}$ \\
\hline $\begin{array}{l}\text { Morning low-level } \\
\text { (MLLJ) }\end{array}$ & 2 & $\begin{array}{l}\text { Falcon with DIAL, HRDL and dropsondes, Lear jet dropsondes, DC-8 } \\
\text { with LASE and S-HIS, Proteus with NAST-I, NWS radiosondes, ISS radio- } \\
\text { sondes, S-Pol, ARM CART radiosondes, SRL, GLOW }\end{array}$ \\
\hline $\begin{array}{l}\text { Evening low-level } \\
\text { jet (ELLJ) }\end{array}$ & 4 & $\begin{array}{l}\text { DC-8 with LASE, Falcon with DIAL and HRDL, Proteus with NAST-I, P-3 } \\
\text { with downward L2 and ELDORA, Lear jet dropsondes, NWS radiosondes, } \\
\text { ISS radiosondes, GLOW, HARLIE, SRL, ISS/MAPR, S-Pol }\end{array}$ \\
\hline Bore & 2 & $\begin{array}{l}\text { UWKA with WCR, S-Pol, FM-CW, ISFFs, ISS radiosondes, ISS/MAPR, SRL, } \\
\text { HARLIE, GLOW, MIPS, AERIBAGO }\end{array}$ \\
\hline $\begin{array}{l}\text { Boundary layer } \\
\text { evolution (BLE) }\end{array}$ & 3 & $\begin{array}{l}\text { UWKA with WCR, P-3 with horizontal L2 and ELDORA, DC-8 with LASE } \\
\text { and S-HIS, Falcon with DIAL and HRDL, S-Pol, DOWs, SMART-R, X-Pol, } \\
\text { MCLASS, MGLASS, ISS radiosondes, NWS radiosondes, ISS/MAPR, TAOS, } \\
\text { FC, MMs, ISFFs, MIPS, MMR, GLOW, HARLIE, SRL, AERIBAGO }\end{array}$ \\
\hline
\end{tabular}

Update Cycle 10-km model (RUC10) and various operational models over the Arkansas-Red River basin River Forecast Center domain on a 32-km grid. Using the NCEP 4-km stage IV precipitation field for verification, the 12-h verification results (Fig. 5), which are representative of the other forecast periods, show that RUC10 displayed the least bias of all the models evaluated for low-precipitation amounts. All of the models [RUC10, 12-km Eta, Nested Grid Model (NGM), and Aviation (AVN)] displayed relatively low equitable threat score (ETS) values, which highlights the warm-season QPF problem that IHOP_2002 was designed to address.

Hourly gauge data were used in the FSL Real-Time Verification System (RTVS) evaluation of the 3-, 6-, and 12-h precipitation forecasts from the various FSL models, the Eta12, and the Weather Research and Forecasting (WRF) 10-km model runs at NCAR. Bias and ETS results for the 3-h forecasts shown in Fig. 6 provided extremely useful information to model de- velopers and were the source for substantive changes to the "hot start" procedure resulting in dramatic improvements to short-range QPF during the latter half of IHOP_2002. Additional information about forecast QPF skill is available from other verification techniques (e.g., Ebert and McBride 2000) and are being explored.

Traditional statistical measures used to evaluate precipitation forecast skill are affected by variations in the resolved scales of the forecasts and observations. This scale-dependence complicates the comparison of precipitation fields that contain differing degrees of small scale detail. This dependence is especially important for IHOP_2002 precipitation verification, because the model precipitation fields exhibit considerable variability in the degree of small-scale detail resolved. Therefore, better understanding of this scale dependence is needed to more accurately evaluate the skill of both operational and research model precipitation forecasts and is a fruitful area for future research. 


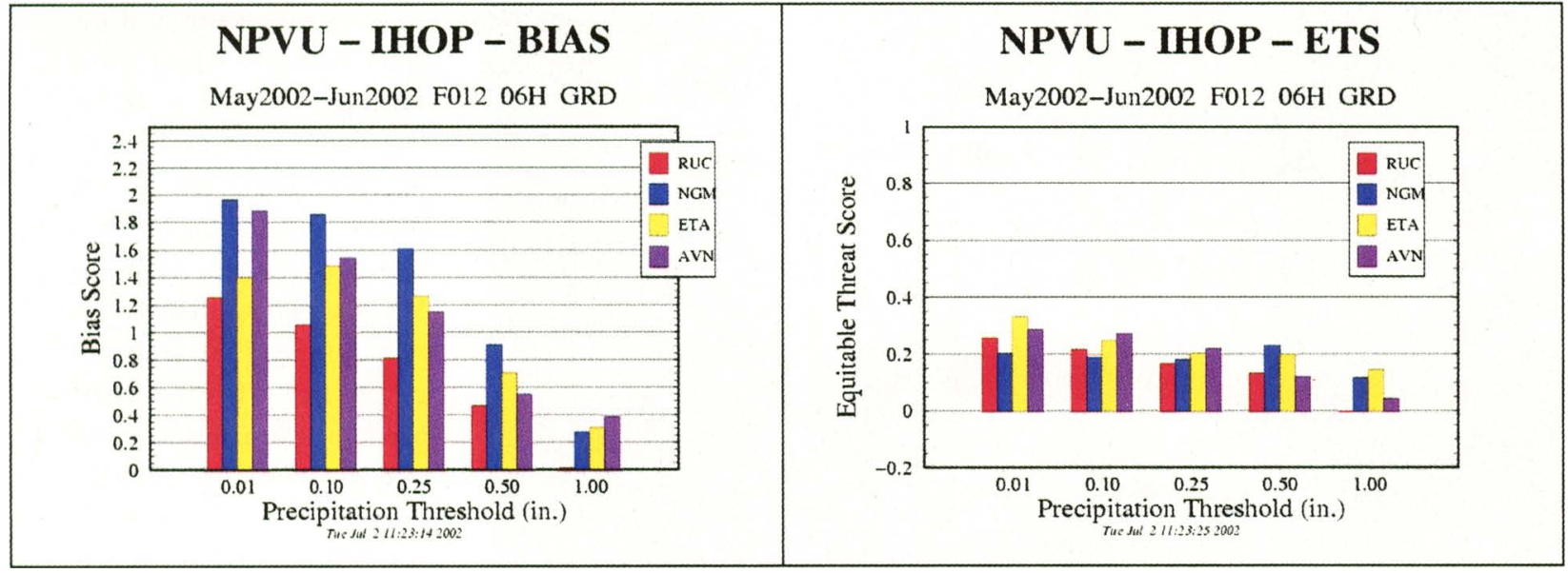

FIG. 5. Comparison of I2-h forecast precipitation skill statistics (bias and equitable threat score) computed by HPC for the experimental RUCIO model and the operational Eta, NGM, and AVN models for I May-30 Jun 2002. Bars are plotted for each of the models for precipitation amounts of $0.0 \mathrm{I}, 0 . \mathrm{I}, 0.25,0.5$, and I.0 in.
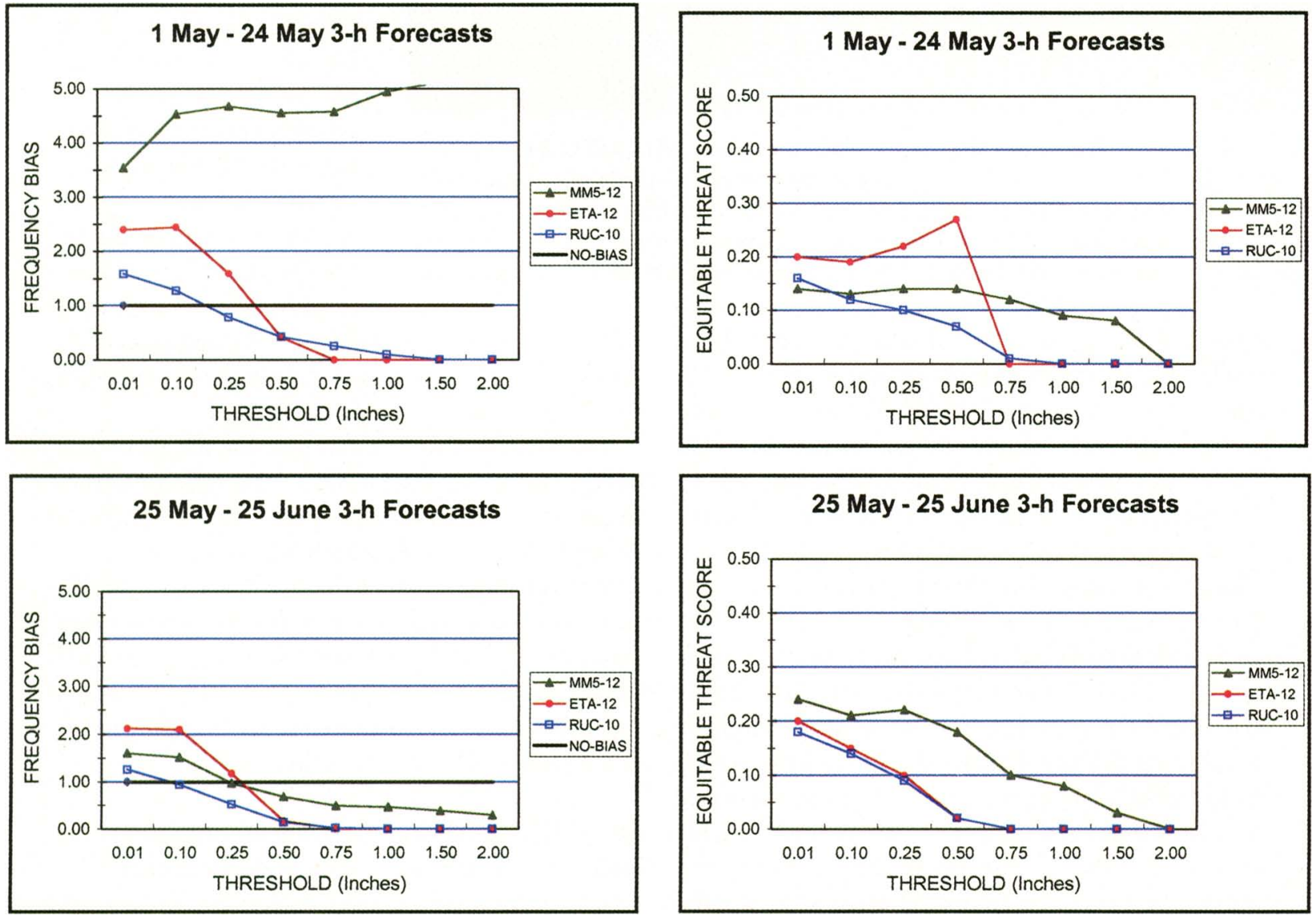

FIG. 6. Verification of forecast 3-h precipitation amounts produced by the MM5 I2-km, Eta I2-km, and RUC $10-\mathrm{km}$ models. (left) Frequency bias and (right) equitable threat score statistics for two time periods during IHOP_2002: (top) I-24 May 2002 and (bottom) 25 May-25 Jun. The statistics for the first half of IHOP_2002 reveal an extreme systematic bias in the MM5 runs. This overforecast precipitation error is essentially eliminated during the second half of the field experiment because of changes made to the LAPS diabatic initialization technique.

Cl. Several CI events were successfully documented during the experiment. One case, 24 May 2002, is shown in Fig. 7 with the visible satellite imagery providing the background for the Oklahoma Mesonet 


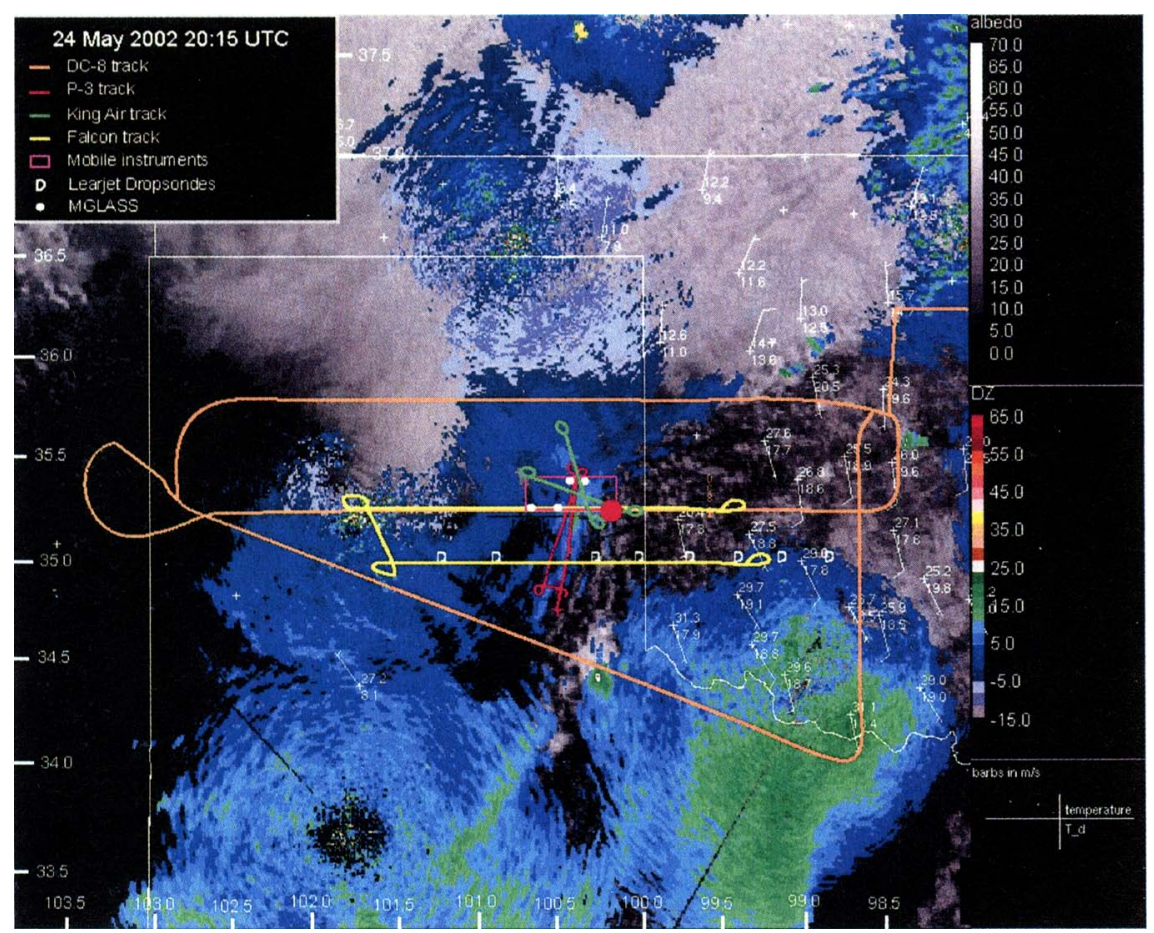

FIG. 7. Visible satellite and radar composite image on 2015 UTC 24 May 2002 prior to $\mathrm{Cl}$. Shown are the flight tracks of the various aircraft, the locations of the mobile ground-based systems, and the available surface station data, plotted with temperature $\left({ }^{\circ} \mathrm{C}\right)$ on top, dewpoint temperature $\left({ }^{\circ} \mathrm{C}\right)$ on bottom, and wind barbs with a full barb of $5 \mathrm{~m} \mathrm{~s}^{-1}$. Shamrock, TX, is at the red circle.

AGL crossing the dryline. Additionally they flew multiple legs penetrating the cold front and a few legs through the triple point. When the UWKA flew above $700 \mathrm{~m} \mathrm{AGL}$, the WCR was operated in vertical-plane dual-Doppler mode. The WCR was operated in simultaneous up and down mode on flight legs below $700 \mathrm{~m} \mathrm{AGL}$, providing single-Doppler data. One of the WCR upward-pointing reflectivity plots and corresponding UWKA in situ measurements is shown in Fig. 8. Note the drastic difference in depth of enhanced reflectivity of the cold frontal zone $(<500 \mathrm{~m} \mathrm{AGL})$ and the dryline $(\sim 1600 \mathrm{~m}$ AGL). This may be attributed to the enhanced lowlevel stability associated

data, the composite radar display with the flight tracks, and locations of mobile vehicles prior to CI. The mobile vehicles and aircraft all intercepted and collected data on a couple of boundaries prior to CI. The focus was Shamrock, Texas, where there was an intersection (i.e., triple point) between a nearly north-south dryline and nearly east-west cold front. The ground-based instruments included two Doppler on Wheels (DOWs), SMART-R, X-Pol, eight mobile mesonet vehicles, three mobile sounding systems, the NSSL field camera, and MIPS. The intensive operation region (IOR) was set up around the developing dryline. During the operations, which included quad-Doppler data collection, the triple point propagated through the center of the IOR. This was the first DC-8/LASE IHOP_2002 mission, and it flew a large-scale racetrack-pattern mapping of the region with $370-\mathrm{km}$ legs from a flight level of $7600 \mathrm{~m}$ MSL. The Falcon with the DLR water vapor DIAL covered a smaller racetrack pattern with $167-\mathrm{km}$ legs. The Learjet dropped nine sondes every $\sim 30 \mathrm{~km}$ from $4700 \mathrm{~m}$ MSL along a leg that was coordinated with the Falcon. The NRL P-3 flew a rectangular pattern straddling the dryline at 305 m AGL and crossing the triple point several times. The UWKA flew multiple $33-\mathrm{km}$ legs from $150 \mathrm{~m}$ AGL up to $2440 \mathrm{~m}$ with a cold front. Such zones of enhanced reflectivity are called fine lines and are known to be potential loci of CI (e.g., Wilson and Shreiber 1986).

Deep convection initiated near the intensive data collection region by 2100 UTC. Data collection from many of the observational platforms commenced around 1800 UTC. Research will be conducted to determine the impact of the boundaries on the CI processes. Data from this day and numerous other positive and null CI events will be extensively analyzed in the coming years in an attempt to better understand the mesoscale to microscale conditions leading to the development of deep convection.

ABL. IHOP_2002 data provided an unprecedented look at the interplay of larger-scale moisture evolution with the land surface, vegetation, and terrain across a region with a strong east-west rainfall gradient that is reflected in changes in land use. The combination of WCR and flight-level data on a total of 15 missions, with data from surface flux stations along three different tracks [over the three sets of Integrated Surface Flux Facility (ISFF) stations of Fig. 3], offers a unique opportunity to (i) study the role of the surface in determining boundary layer structure and fluxes and (ii) use that knowledge to improve land 


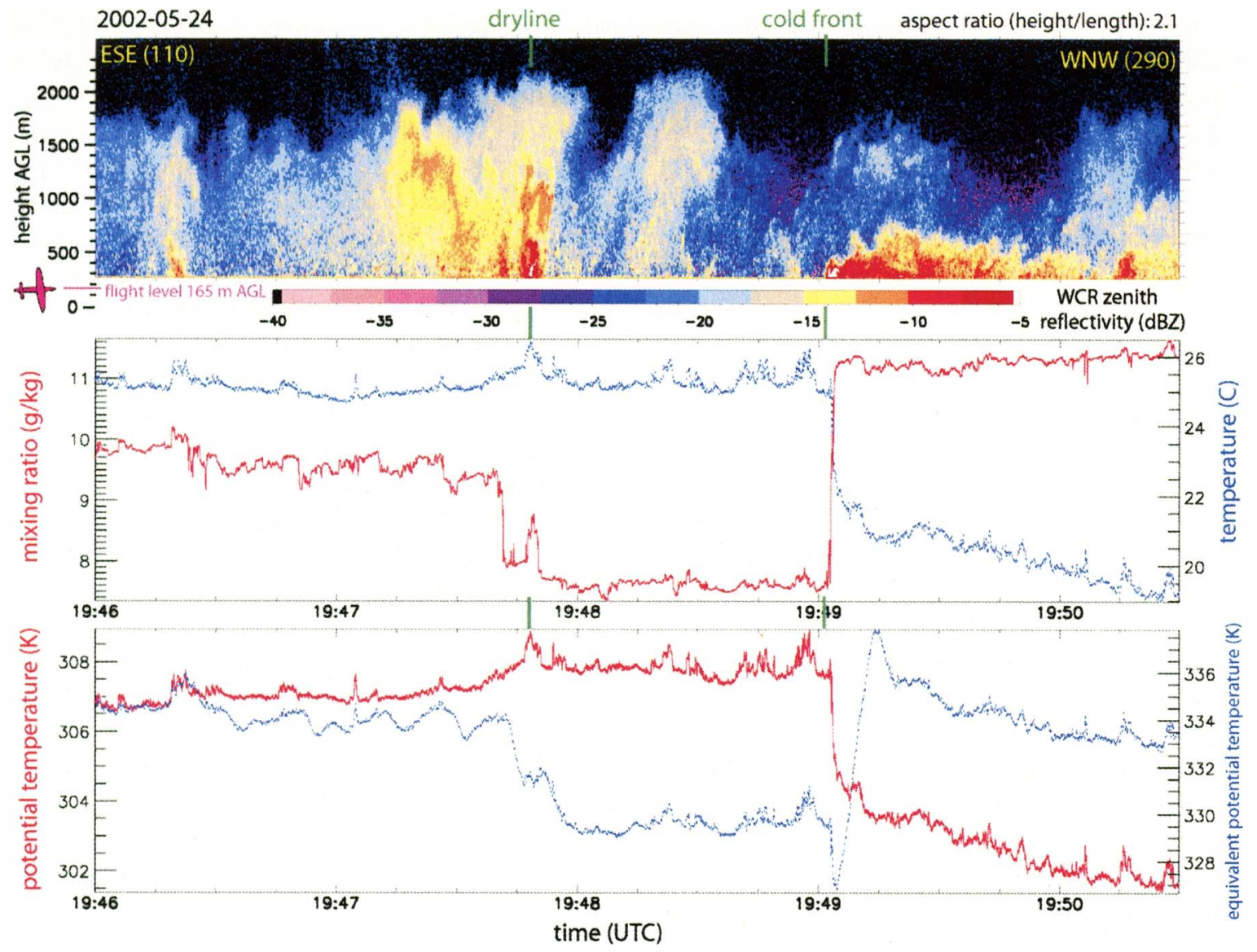

FIG. 8. WCR reflectivity profile above the $165-\mathrm{m}-A$ GL flight level, along a 22-km-long transect from ESE to WNW on 24 May 2002 in northern Texas, showing a relatively strong, shallow ( $\sim 500 \mathrm{~m}$ deep) cold front and a weaker but deeper dryline signature ( 1800 m deep). The corresponding UWKA in situ measurements below clearly show the dryline and cold frontal signatures indicated by vertical green lines.

surface and boundary layer parameterization schemes in numerical weather forecast models, which should in turn result in better prediction of summertime precipitation (Beljaars et al. 1995; Chen et al. 1998).

Figure 9 uses plots of radiometric surface temperature (a measure of the nearsurface soil temperature, which is related to soil moisture) versus Normalized Differential Vegetation Index (NDVI), a measure of the density and greenness of vegetation, from the UWKA to illustrate the range of conditions encountered. The data in the
IHOP 29 May - 31 May 2002 King Air Missions Sample Legs at $60 \mathrm{~m}$

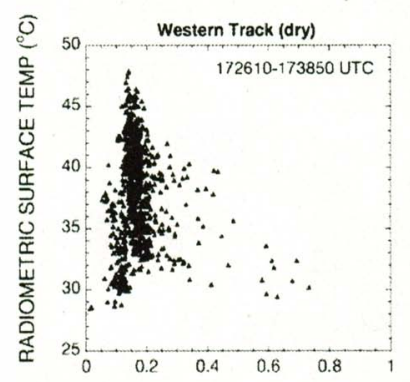

Station 1: $150 \mathrm{~mm}$ Station 2: $\quad 68 \mathrm{~mm}$ Station 3: $\quad 68 \mathrm{~mm}$

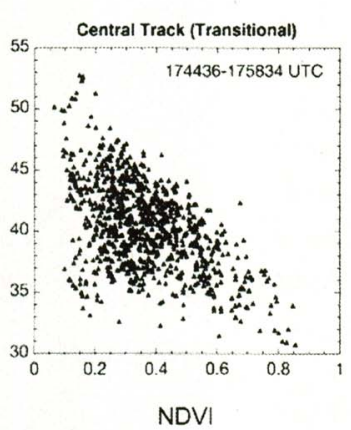

Station 4: $125 \mathrm{~mm}$ Station 5: $144 \mathrm{~mm}$ Station 6: $212 \mathrm{~mm}$

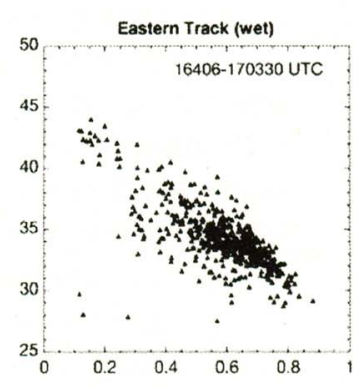

Station 7: $170 \mathrm{~mm}$ Station 8: $285 \mathrm{~mm}$ Station 9: $240 \mathrm{~mm}$
FIG. 9. Summary plots of 29-3I May 2002 UWKA-measured radiometric surface temperature vs NDVI for (left) western, (middle) central, and (right) eastern low-level UWKA flight tracks over the three corresponding sets of ISFF sites of Fig. 3. The ISFF station numbers on the bottom list the corresponding surface rainfall measurements. 
left panel are from the western track near the Homestead Profiling Site. In this case, the radiometric surface temperature is mainly related to the soil moisture, with the NDVI values consistent with sparse vegetation characteristic of the dry climate in this region, which was experiencing a severe drought. In contrast, the data from the eastern track shows that radiometric surface temperature is strongly related to NDVI, with the coolest readings corresponding to the greenest, most lush vegetation. Vegetation beneath the eastern track was mostly grassland with trees along property lines and riparian zones; this area received about twice as much precipitation as the western track. At the central track, the surface temperature is influenced by both soil moisture and vegetation, which was a mix of winter wheat and grassland. The surface flux stations were sited to obtain a representative sample of the dominant vegetation: six were located on grassland of varying thickness, two on winter wheat, one on bare ground, and one on scrubland.

It is likely that the ABL dataset will allow a relatively complete observational investigation of how the atmosphere responds to local regions of increased soil moisture under conditions of strong insolation. IHOP_2002 investigators are planning large-eddy simulations of this event.

Flux, weather, vegetation, and soil data from the surface flux stations, surfacecharacterization data, radar-rainfall data, and satellite data will be used to produce a horizontal field of soil moisture and fluxes to drive such models. The combined modeling and observational efforts will finally allow for an accurate evaluation of hypotheses on how mesoscale circulations within the boundary layer develop in response to surface gradients, which have been developed almost exclusively on the basis of numerical simulations (e.g., Anthes et al. 1982; Segal and Arritt 1992; Chen and Avissar 1994; Avissar and Schmidt 1998).

A relatively new product to map the refractivity field surrounding S-Pol was utilized in IHOP_2002. This refractivity retrieval algorithm is an ingenious technique to retrieve surface layer refractivity measurements (closely related to moisture measurements) from ground targets (Fabry et al. 1997). The technique uses fixed ground targets to relate variations in Doppler signal delay to variations in the intervening atmospheric refractivity field. The refractivity field approximately $30 \mathrm{~min}$ after the data from the left panel of Fig. 9 were obtained shows a mesoscale area of cool and moist air (Fig. 10). This illustrates the atmosphere's response to a local region of increased soil moisture and widespread standing water caused by locally heavy rainfall on a preceding day. The temperature, humidity, and pressure at nearby ISFF flux stations are consistent with the refractivity field. The UWKA flight-level data, gathered during four sets of $50-\mathrm{km}$ north-south legs at four levels on this day are listed in the boxes of Fig. 10. The WCR reveals that the thermodynamic differences translate into a deeper and more vigorous boundary layer at the northern, dry end of the track.

The refractivity field also often reveals boundaries corresponding to the traditional reflectivity fine lines and velocity convergence zones. One day in particular, 22 May 2002, exhibited strong gradients in refrac-

FIG. 10. Radar refractivity retrieval over strongly heterogeneous soil moisture conditions at 1700 UTC 29 May 2002 after heavy rainfall occurred south of S-Pol two days earlier. The higher refractivity values shown in blue indicate relatively moist, cool air. The red line shows the UWKA flight track at $60 \mathrm{~m}$ $A G L$, and boxes give corresponding variations in radiometric surface temperature $\left(T_{s}\right)$, UWKA potential temperature $\left(\theta_{60}\right)$, and UWKA mixing ratio $\left(q_{60}\right)$.

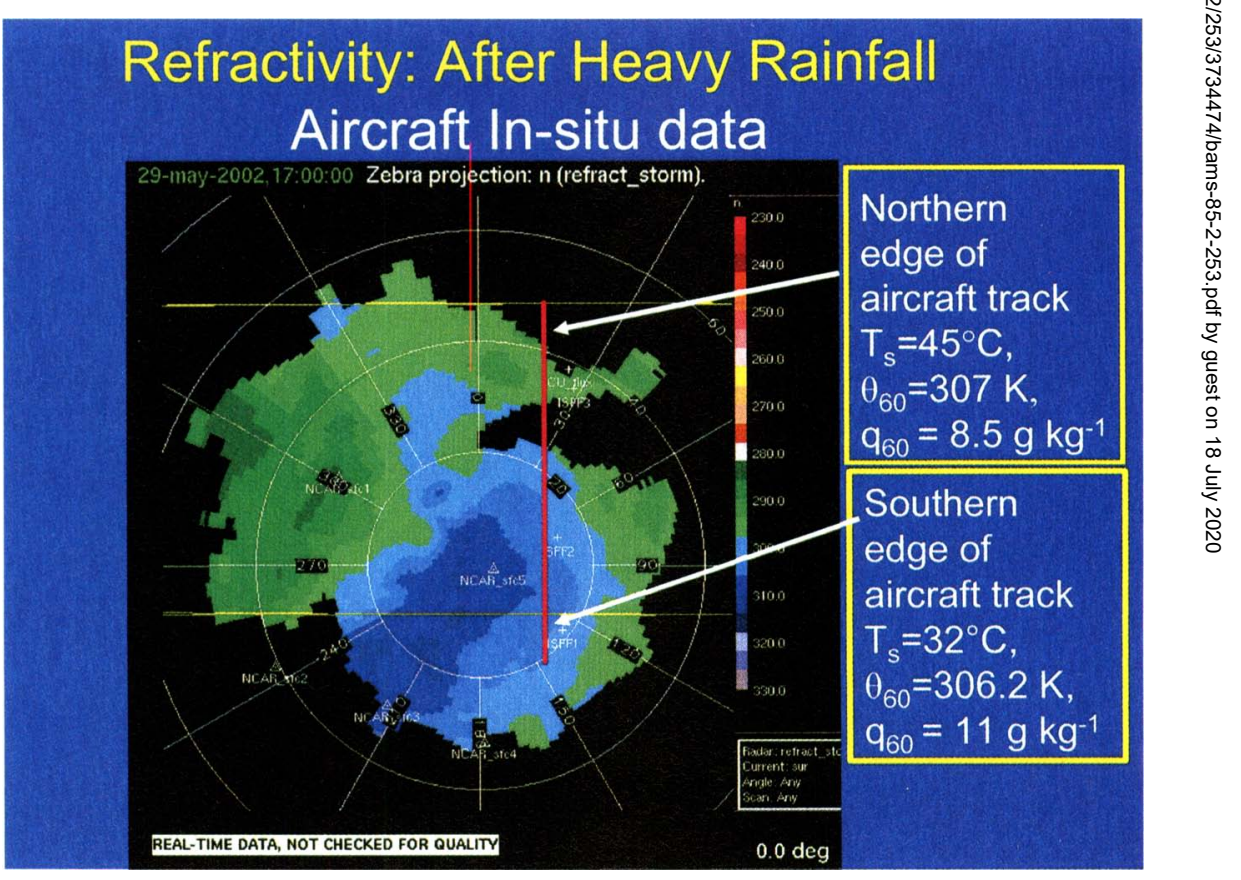


tivity (please see "Movie Loop: 22 May Refractivity" at www.atd.ucar.edu/dir_off/projects/2002/ IHOP.html). Aircraft tracks on this day were actually designed based on the refractivity observations since they showed obvious gradients prior to the formation of fine lines and convergence zones. The tightening of the dryline moisture gradient was apparent in the refractivity loop, which showed a NNE-SSW gradient near S-Pol beginning about 1900 UTC. The corresponding time-height plot of water vapor mixing ratio (3-min averages), measured by the NASA Goddard Space Flight Center SRL during the afternoon of 22 May 2002, is shown in Fig. 11. The growth of the boundary layer and subsequent demise after sunset ( 0040 UTC), as well as the associated dryline structure, are readily seen. The S-Pol refractivity movie loop shows that the cool/moist air mass over the Homestead site was being quickly "pushed" east and replaced by the warm/dry conditions. The dry air reached the Homestead area around 2130 UTC, where the SRL shows a decrease in mixing ratio. Dry conditions persisted until about 2230 UTC, followed by increased moisture up to $1-\mathrm{km}$ altitude. This was also observed in the refractivity data as a retreat of the dry air mass. The moist air mass became well defined through the rest of the measurement time (until past 0300 UTC into the night). It is important to note that the decrease in moisture observed prior to sunset could very well be a result of the dry air mixing from above and subsequent growth of the boundary layer, which could cause an apparent eastward movement of the dryline (Parsons et al. 2000).

These boundaries and other features apparent from the refractivity field will be examined to evaluate their impact on $\mathrm{ABL}$ evolution, ABL heterogeneity, and CI processes. In addition to these research aspects, there are also significant operational implications. For example, at times, the refractivity field illustrated boundaries up to several hours prior to the appearance of boundaries in the other more traditional Doppler velocity and radar reflectivity fields. The real-time availability of the field was such that aircraft were deployed substantially earlier with the added information. The importance of these facts to nowcasting the onset of convection cannot be overestimated since most current nowcasting systems rely heavily on monitoring the location and behavior of boundaries, as illustrated in radar fine-lines signals (Wilson et al. 1998). In addition, assimilation of these measurements may also improve the ability to predict storm systems using numerical models (e.g., Montmerle et al. 2002). The possibility of utilizing radar refractivity techniques to improve short-term prediction of convective storms will be examined. Fortunately, the technique will not be difficult to implement on WSR-88D systems once the new processors are implemented.

Instrumentation. Numerous instrument intercomparisons will be conducted between the many different types of remote sensors (Table 1), between remote and in situ sensors, and between different types of in situ sensors in order to assess instrument accuracy and temporal/spatial variability. Such intercomparisons were a primary factor in locating the ground-based systems and in designing many of the aircraft flight tracks.

Some preliminary intercomparison results that will have significant impact on both operational and research meteorology were obtained from the reference radiosonde system. This state-of-the-art sounding package can be flown on the same balloon as opera-
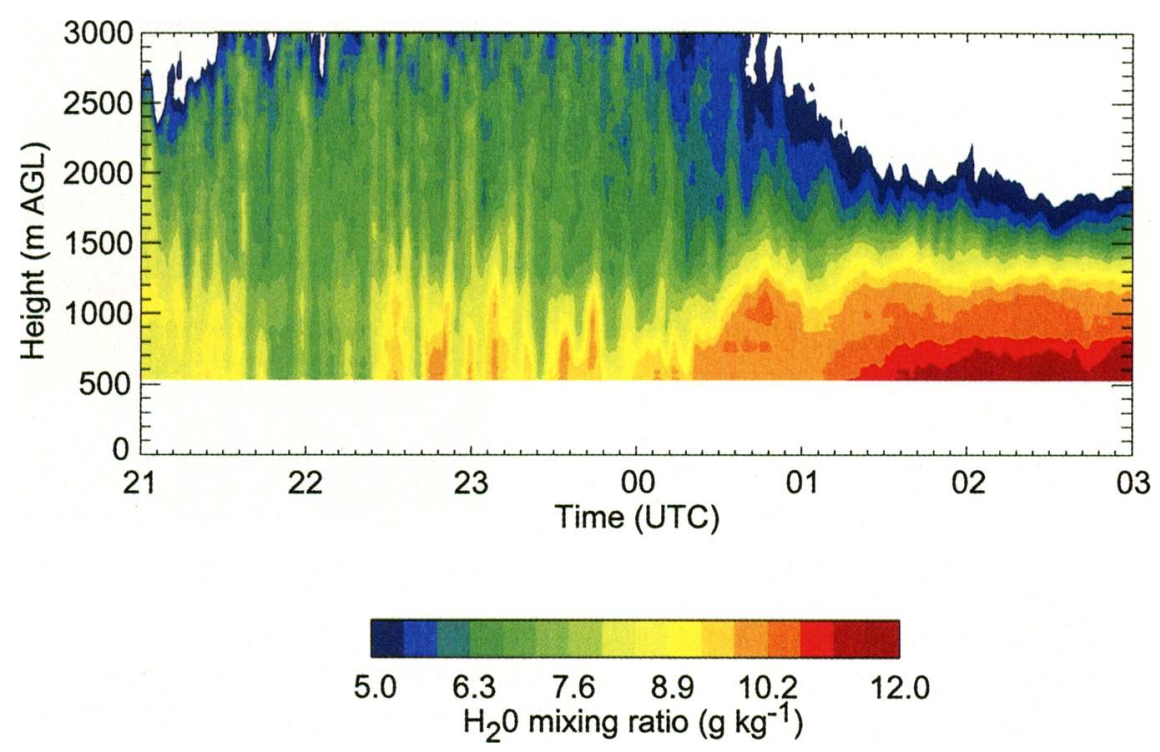

FIG. I I. Time-height plot of water vapor mixing ratio from SRL from 2100 UTC 22 May 2002 through 0300 UTC 23 May 2002. Data were averaged to 100200-m vertical resolution every $3 \mathrm{~min}$. This plot corresponds with the S-Pol refractivity movie loop, which may be viewed at http://www.atd.ucar.edu/ dir_off/projects/2002/IHOP.html under “Movie Loop: 22 May Refractivity." 
tional sounding packages. An intercomparison of the Swiss Snow White chilled-mirror dewpoint hygrometer, which is the reference humidity sensor, with the carbon hygristors inside the reference sonde and inside the NWS operational VIZ radiosonde is shown in Fig. 12a (Wang et al. 2003). It is apparent that substantial variations exist between the reference and the operational radiosonde moisture measurements at all levels. At extremely low temperatures (i.e., high altitudes), in particular, there is an alarmingly poor response from the hygristor. Note the Snow White observations of high humidities at 11-12 km AGL suggestive of a cirrus layer. Although it was not visible in the satellite imagery, the SRL detected an enhanced aerosol depolarization layer at that level (Fig. 12b), also suggesting an optically thin cirrus layer (Whiteman et al. 2001).

The implications of these reference radiosonde comparisons with research and operational sounding datasets are critical for not only weather prediction, but also for understanding climate change and radiative processes. For example, as pointed out by Crook (1996), the difference between intense storms and a nonconvective day can sometimes hinge on relatively small humidity differences in the lower troposphere that are within the measurement error of the operational systems. Climate and radiational implications of radiosonde errors are discussed, for example, in Guichard et al. (2000), Wang et al. (2002), and Turner et al. (2003).

Bores. One of the surprising observations during IHOP_2002 was the multitude of bore events in the region. Bores indicated in (b). may be produced when a cold front or outflow boundary impinges upon a stable surface layer in the presence of sufficient wind curvature. Bores cause a "permanent" displacement of a layer aloft while at-
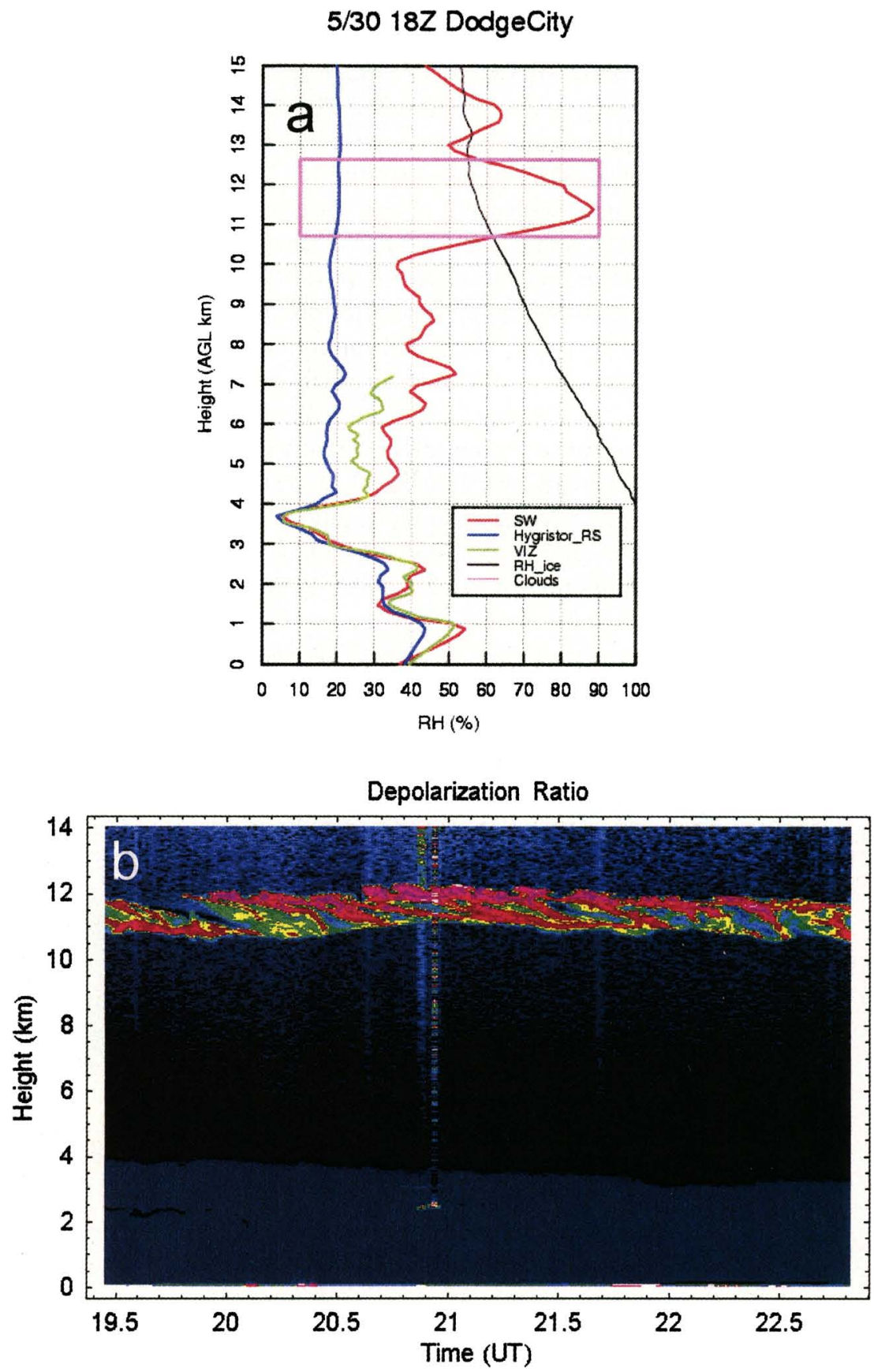

FIG. I2. (a) Relative humidity intercomparisons between Snow White chilledmirror dewpoint hygrometer reference sensor (red), carbon hygristor (blue), and VIZ carbon hygristor (green) on 30 May 2002. The relative humidity with respect to water at ice saturation (black) is also shown. (b) Time series of SRL aerosol depolarization measurements showing cirrus layer at II-I $2 \mathrm{~km}$. Note the Snow White observations of high humidities at I I$12 \mathrm{~km} \mathrm{AGL}$ in (a) corresponding to a thin cirrus layer (magenta box) as 
mospheric solitary waves occur when a layer is displaced upward and then returns back to its original height. However, since Christie et al. (1979) and Skyllingstad (1991) clearly make the case that under proper conditions bores can evolve into solitary wave systems, solitary wave events are included in this bore discussion.

Early investigators (e.g., Tepper 1950; Abdul 1955) were intrigued by observations of strong wave-related surface pressure perturbations and proposed that vertical motions arising from low-level gravity wave disturbances could initiate convective storms over the

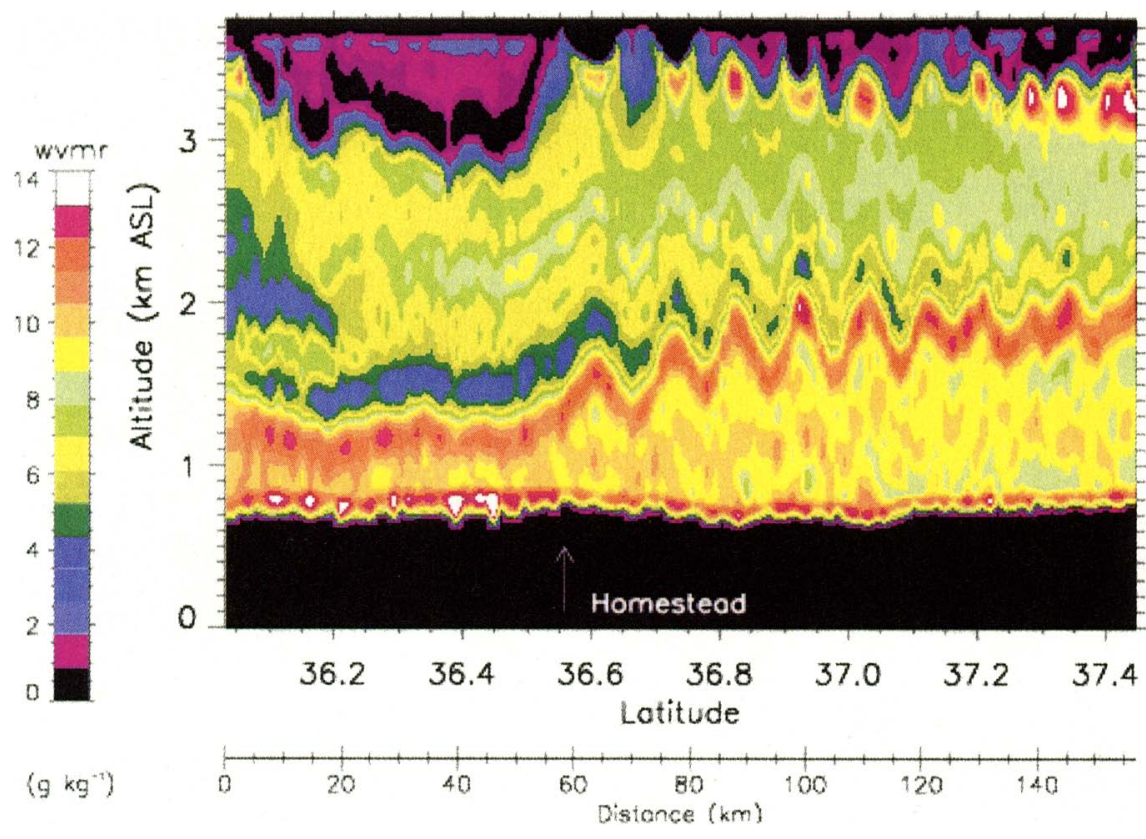

FIG. 13. Leandre II downward-pointing DIAL water vapor mixing ratio field from NRL P-3 0555-0616 UTC 20 Jun 2002. The waves apparent in the moisture field are associated with a bore propagating beneath the aircraft. central plains. Since the early studies there have been numerous case study analyses of data taken over this region showing solitary waves and borelike disturbances (e.g., Shreffler and Binkowski 1981; Doviak and Ge 1984; Fulton et al. 1990; Doviak et al. 1991; Koch et al. 1991; Mahapatra et al. 1991) and associated examples of convection initiation in which these wave events played a role (Carbone et al. 1990; Karyampudi et al. 1995; Koch and Clark 1999; Koch et al. 2001; Locatelli et al. 2002). Doviak et al. (1991) argue that these events "might be a commonly occurring feature in the neighborhood of thunderstorms whenever suitable atmospheric stratification exists and sources are active" and indeed borelike disturbances have commonly been observed in northern Australia (for a review see Menhofer et al. 1997). However, the observational investigations of solitary waves/bore events over the SGP have been primarily limited to individual case studies, often using detailed measurements taken at a single location. The IHOP_2002 measurements are well suited to a more systematic investigation of bore events, particularly because of the complete radar coverage afforded by the real-time radar composites. The measurements from aircraft and the fixed remote sensing systems also allow unprecedented investigations into bore structure and evolution.

One of the more spectacular bore events was sampled during a low-level jet mission designed to study the mesoscale circulations associated with the

development and maintenance of nocturnal convective systems. Figure 13 shows the downward-pointing Leandre II water vapor DIAL on board the P-3 aircraft, which obtained an impressive image of the water vapor structure in association with the bore. At least nine wavelike features are apparent in the water vapor distribution. These data suggest lifting of the low-level moist air by the bore in that the moist boundary layer rises from $\sim 800 \mathrm{~m}$ AGL ahead of the bore to a depth of $\sim 1.7 \mathrm{~km}$ AGL well behind the leading edge of the bore. Although CI did not occur in association with this event, the bore has modified the inflow conditions to be more favorable to deep convection with a deeper moist layer and a likelihood of a weaker capping inversion through lifting.

Two spectacular bore events occurred in the early morning of 4 June 2002. One bore occurred in association with a weakening outflow boundary, and the other was generated along a southward-advancing cold front. S-Pol radar reflectivity showed reflectivity fine lines and a train of waves with a spacing of $\sim 10 \mathrm{~km}$ to its rear suggestive of solitary waves atop a bore (Fig. 14). An impressive set of measurements from the FM-CW radar (not shown), the MAPR system (Fig. 15), and the ISS surface station (Fig. 16c) at the Homestead Profiling Site show amplitude-ordered solitary waves. A billowing upward of the 750-m-deep nocturnal inversion surface appeared suddenly at 0625 UTC in Fig. 15, followed by the waves, indicat- 


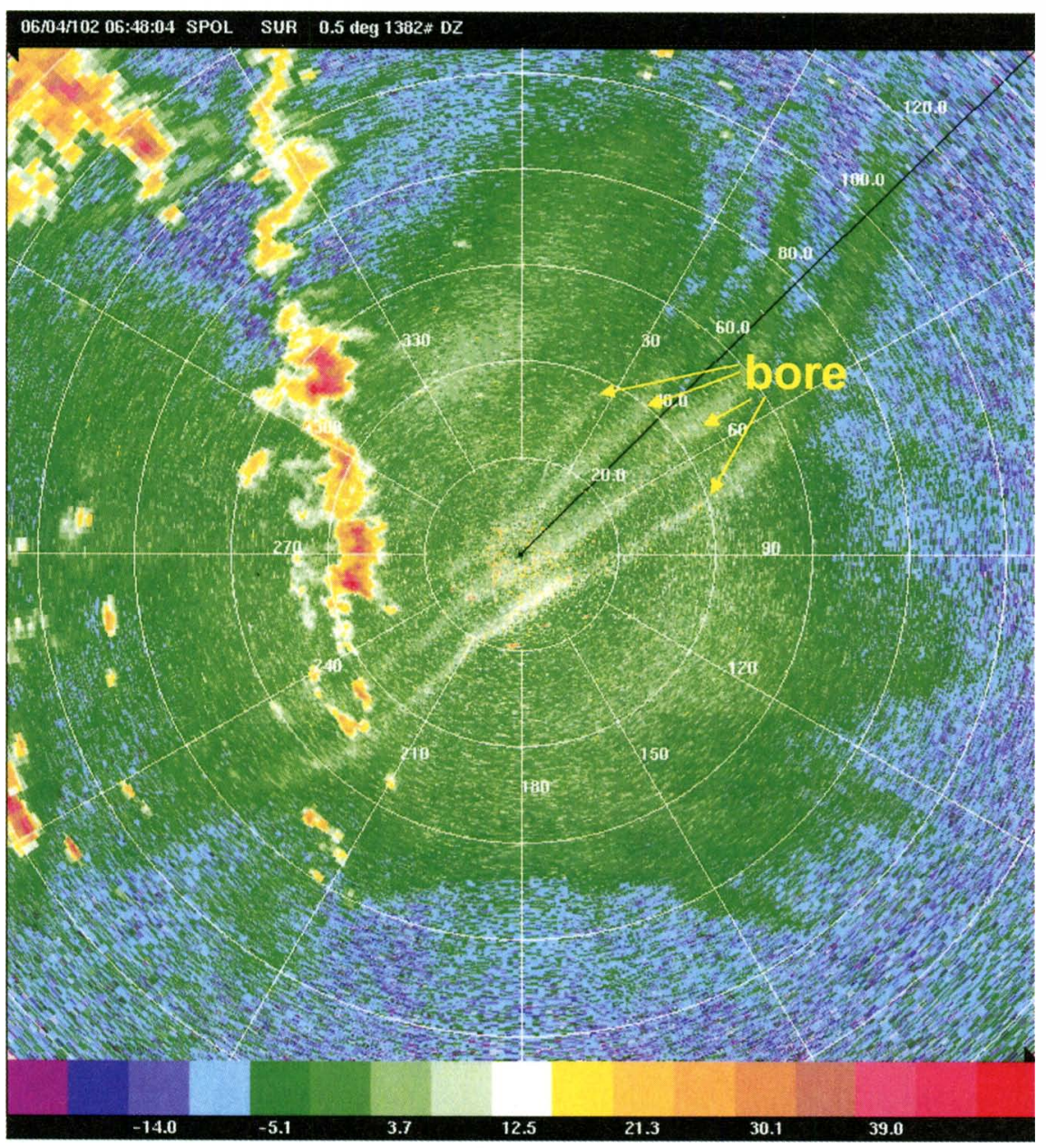

FIG. I4. Approach of a wavelike bore over the Homestead Profiling Site ( 7 km east of S-Pol) as seen by S-Pol's $0.5^{\circ}$ elevation angle reflectivity display for 0648 UTC 4 Jun 2002. ing that the bore had lifted the moist air and weakened the capping inversion. Updrafts and downdrafts preceded and followed all of the wave crests, respectively, and appeared to have maximum amplitudes of $\sim 2 \mathrm{~m} \mathrm{~s}^{-1}$ and were observed as high as $3.5 \mathrm{~km}$. Interferometric observations from a collocated AERI system (Figs. 16a and 16b) show that cooling and moistening occurred above the surface layer at $0630-0730$ and 1100-1230 UTC with the passage of both bores. Tentative hypotheses resulting from the synthesis of these observations are being developed and will be tested with extremely highresolution models initialized with the IHOP_2002 data. Subsequent work will also examine the dynamics of these borelike disturbances and their impact upon convection initiation and maintenance.
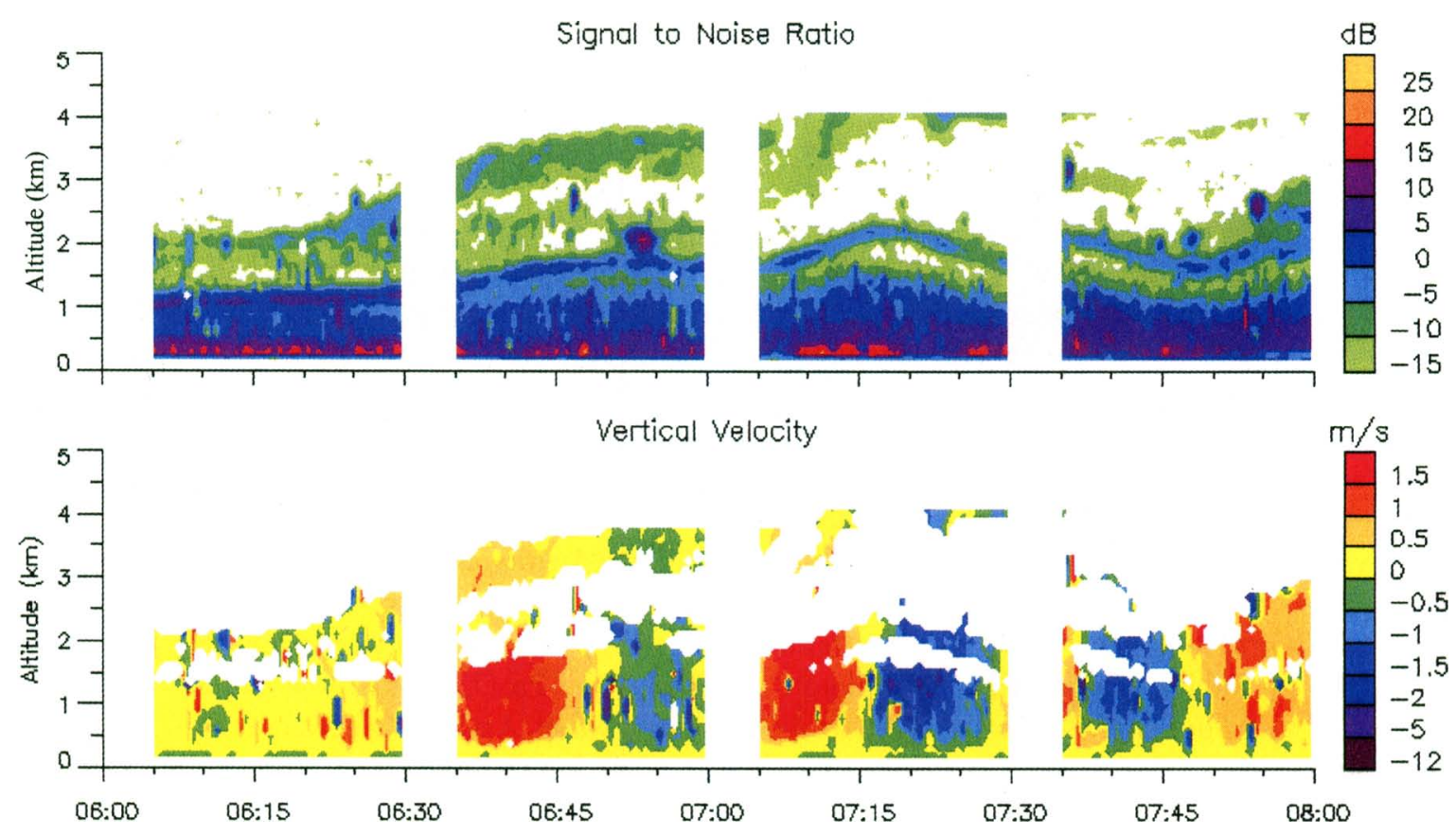
SUMMARY. Teams of international investigators will likely use IHOP_2002 data for years to come. These datasets will allow for some of the first comprehensive mesoscale studies of the moisture fields along with temperature and wind fields with the aim of (i) assimilating these data into numerical models to ascertain the relative impact on QPF; (ii) better understanding and pinpointing exactly why, when, and where convective storms form; (iii) evaluating the relationship between land surface heterogeneities and boundary layer moisture distribution; and (iv) determining the future optimal mix of operational groundbased and satellite-borne moisture sensing instruments and assimilation techniques for forecasting convective rainfall. While the experimental design was hypothesis-driven, some of the lasting impacts of the experiment will likely be unexpected discoveries concerning the basic thermodynamic and dynamic nature of the atmosphere, as illustrated by the discussion concerning the ubiquity of bore events. These discoveries are expected since the experiment was one of the first efforts to map time variations in the threedimensional water vapor field with sensors sometimes deployed either for the first time for weather studies or in unique combinations.

Creating maps of the water vapor distribution will be a long-term research effort performed in part by several groups and overseen by the IHOP_2002 Project Office. IHOP_2002 will take the critical step of developing a four-dimensional integrated water vapor dataset to fully assess the value of such measurements in better measurement strategies for operational forecasts and for meaningful data assimilation. Currently efforts are underway to perform quality control intercomparisons among the various water vapor sensors. After this is achieved data assimilation on several scales utilizing various datasets will be performed with the ultimate goal of obtaining a 3D, timevarying water vapor distribution map to be used by both research modelers and observationalists.

The experimental effort was broad, and this short article could not do justice to the many exciting datasets collected and preliminary results obtained. Thus early highlights within each of the four components were arbitrarily selected. Further examples of datasets collected during IHOP_2002 may be viewed online at www.joss.ucar.edu/ihop/catalog/. Use of these datasets
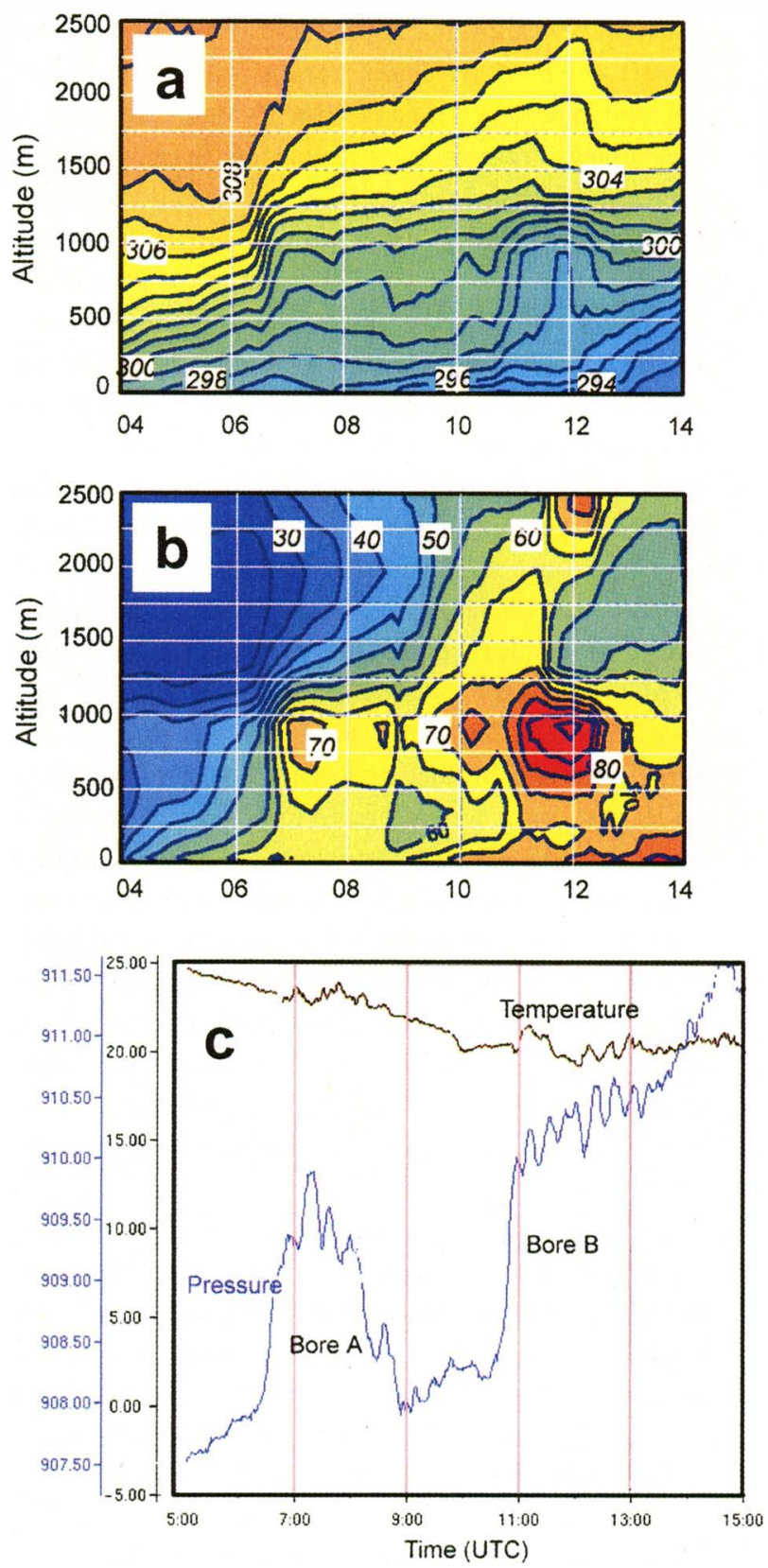

FIG. 16. Comparison of thermodynamic changes caused by passage of the bore as seen by (a) AERI potential temperature (K) and (b) AERI relative humidity (\%) profiles at the Homestead Profiling Site and (c) pressure $(\mathrm{hPa})$ and temperature $\left({ }^{\circ} \mathrm{C}\right)$ time series recorded by the ISS mesonet station at the Homestead Profiling Site.

is subject to the IHOP_2002 data policy and those of the participating agencies that collected the datasets.

FIG. I5 (facing page) Solitary wave train within the bore system as seen in the MAPR (top) signal-to-noise ratio data and (bottom) vertical velocity data for the period 0600-0800 UTC 4 Jun 2002. Updrafts are red and downdrafts are blue in this display $\left(\mathrm{m} \mathrm{s}^{-1}\right)$. Note undulations in the height of the nocturnal boundary layer produced by the bore. 
ACKNOWLEDGMENTS. This large international project would not have been possible without the unfailing support of Steve Nelson of the NSF's Mesoscale Dynamic Meteorology Program. We also gratefully acknowledge the early and continued support of David Carlson during his tenure as director of NCAR/ATD. The support of Bob Gall, the lead scientist of the USWRP, and the members of the USWRP Interagency Working Group, particularly Jim Dodge of NASA HQ and John Gaynor of NOAA/OAR, were crucial in making this experiment an interagency effort. Beyond the agencies of the USWRP, the program managers of NPOESS and the French, German, and Canadian managers are thanked for allowing this grass roots scientific effort to grow into a major international campaign. NSF support of the IHOP_2002 Project Office is greatly appreciated. These funds supported the expert logistical assistance by Melinda Tignor (NCAR) and the Joint Office for Science Support (UCAR/JOSS). Invaluable planning and field work was also performed by Brigitte Baeuerle (NCAR).

Heroic efforts were required to prepare and upgrade many of the IHOP_2002 instruments in time for the field phase. These efforts included but were not limited to major modifications to the NRL P-3, UWKA, and DLR Falcon aircraft. Much gratitude is bestowed upon all of those groups and agencies for ensuring that their commitments of participation were achieved with the best possible instrumentation and upgrades available. Many scientists participated in the extensive planning of the project and are gratefully acknowledged.

Field support from the multitude of people representing all of the instruments listed in Table 1, as well as additional support from operational instrument technicians, engineers, and mission and instrument scientists is greatly appreciated. Numerous graduate and Research Education for Undergraduate (REU) students provided valuable assistance. Outstanding field support was obtained from Alex Cress (USAF), who was the liaison between the operations center, the scientists, the FAA, and military air traffic controllers and the pilots, and Bob Conzemius (OU), a volunteer graduate student who was the primary communicator between the operations center and all of the fixed and mobile ground-based instruments. Invaluable forecasting support was provided by the SPC, particularly Bob Johns, and their network of volunteers from various NOAA agencies and Iowa State University. Excellent and nearly continuous nowcasting support was provided by Ed Szoke (NOAA/FSL) and John Brown (NOAA/FSL). All of the pilots from the various agencies did a remarkable job of working with the scientists and coordinating missions. In particular, the P-3 pilots, led by Jace Dasenbrock (NRL), and the UWKA pilots, led by Wayne Sand (University of Wyoming), did an outstanding job to achieve the best and most coordinated data collection on a large number of

flight hours in hot and difficult conditions. Excellent planning, field support, and coordination was obtained by the Oklahoma Mesonet, ARM, ABLE, NASA, NOAA, and NPOESS. Thanks to NOAA/NSSL and SPC for use of their facilities during the field phase.

Crystalyne Pettet (NCAR) prepared many of the figures and tables in this manuscript. Jim Wilson (NCAR) created the refractivity movie loop on 22 May 2002. The authors are grateful to Morris Weisman (NCAR), Nita Fullerton (FSL), Seth Gutman (FSL), Peter Blanken (CU), and two anonymous reviewers for their critical reviews of an earlier version of this manuscript. The first two authors' research and field participation was partially supported by an NCAR/USWRP grant.

\section{APPENDIX: LIST OF ACRONYMS AND AB- BREVIATIONS USED IN THIS MANU. SCRIPT AND ON THE WEB LINKS.}

$A B L$

ABLE

$\mathrm{ABQ}$

AERI

AERIBAGO

$\mathrm{AFB}$

AGL

AMA

ARM

ARPS

ATD

AWIPS

AWOS

BL

BLE

BLH

CAPS

CART

$\mathrm{CB}$

$\mathrm{CBL}$

$\mathrm{CF}$

CI

CNRS

CODI

CRAFT atmospheric boundary layer

Argonne Boundary Layer

Experiments

Albuquerque, New Mexico

atmospheric emitted radiance

interferometer

mobile atmospheric emitted radiance interferometer

Air Force Base

above ground level

Amarillo, Texas

Atmospheric Radiation Measurement Program

Advanced Regional Prediction System (CAPS-OU)

Atmospheric Technology Division

Advanced Weather Interactive

Processing System

Automated Weather Observing

System

boundary layer

boundary layer evolution

boundary layer heterogeneity

Center for the Analysis and Prediction of Storms

Cloud and Radiation Testbed

cumulonimbus

convective boundary layer

central facility

convection initiation

Centre Nationale de la Recherche

Scientifique, France

compact DIAL

Collaborative Radar Acquisition Field

Test 


\begin{tabular}{|c|c|c|c|}
\hline СTP & cloud-top pressure & MAF & Midland, Texas \\
\hline $\mathrm{CU}$ & University of Colorado & MAPR & Multiple Antenna Profiler \\
\hline $\mathrm{Cu}$ & cumulus & MCLASS & Mobile Cross-chain Loran \\
\hline DDC & Dodge City, Kansas & & Atmospheric Sounding System \\
\hline DIAL & differential absorption lidar & MCS & mesoscale convective system \\
\hline DLR & $\begin{array}{l}\text { Deutsche Luft und Raumfahrt, } \\
\text { Germany }\end{array}$ & MGLASS & $\begin{array}{l}\text { Mobile GPS/Loran Atmospheric } \\
\text { Sounding System }\end{array}$ \\
\hline DNR & Denver, Colorado & MIPS & mobile integrated profiling system \\
\hline DOW & Doppler on Wheels & MLLJ & morning low-level jet \\
\hline DRI & Desert Research Institute & MM & mobile mesonet \\
\hline DYX & Dyess AFB, Texas & MM5 & fifth-generation Pennsylvania State \\
\hline EAX & Kansas City, Missouri & & University-NCAR Mesoscale Model \\
\hline ELDORA & Electra Doppler Radar & MMR & Mobile Microwave Radiometer \\
\hline ELLJ & evening low-level jet & MOA & military operations area \\
\hline EMC & Experimental Modeling Center & MSL & above mean sea level \\
\hline ETL & $\begin{array}{l}\text { Environmental Technology } \\
\text { Laboratory }\end{array}$ & NASA & $\begin{array}{l}\text { National Aeronautics and Space } \\
\text { Administration }\end{array}$ \\
\hline ETS & equitable threat score & NAST & NPOESS Aircraft Sounder Testbed \\
\hline FAA & Federal Aviation Administration & NCAR & National Center for Atmospheric \\
\hline $\mathrm{FC}$ & field coordination vehicle & & Research \\
\hline FDX & Cannon AFB, New Mexico & NCEP & National Centers for Environmental \\
\hline $\mathrm{FM}-\mathrm{CW}$ & Frequency Modulation-Continuous & & Prediction \\
\hline & Wave radar & NDVI & Normalized Differential Vegetation \\
\hline FSL & Forecast Systems Laboratory & & Index \\
\hline FWD & Fort Worth, Texas & NESDIS & National Environmental Satellite, \\
\hline FX-Net & $\begin{array}{l}\text { FSL weather product analysis/display } \\
\text { system }\end{array}$ & NEXRAD & $\begin{array}{l}\text { Data, and Information Service } \\
\text { Next-Generation Weather Radar }\end{array}$ \\
\hline GLD & Goodland, Kansas & & (WSR-88D) \\
\hline GLOW & $\begin{array}{l}\text { Goddard Lidar Observatory for } \\
\text { Winds }\end{array}$ & $\begin{array}{l}\text { NGM } \\
\text { NOAA }\end{array}$ & $\begin{array}{l}\text { Nested Grid Model } \\
\text { National Oceanic and Atmospheric }\end{array}$ \\
\hline GOES & Geostationary Operational & & Administration \\
\hline & Environmental Satellite & NPN & NOAA Profiler Network \\
\hline GPS & global positioning system & NPOESS & National Polar Orbiting Environmental \\
\hline HARLIE & $\begin{array}{l}\text { Holographic Airborne Rotating Lidar } \\
\text { Instrument Experiment }\end{array}$ & NPVU & $\begin{array}{l}\text { Satellite System } \\
\text { national precipitation verification unit }\end{array}$ \\
\hline HRDL & high-resolution Doppler lidar & NRC & National Research Council \\
\hline $\mathrm{HPC}$ & Hydrometeorological Prediction & NRL & Naval Research Laboratory \\
\hline & Center & NSF & National Science Foundation \\
\hline ICT & Wichita, Kansas & NSSL & National Severe Storms Laboratory \\
\hline IHOP_2002 & International $\mathrm{H}_{2} \mathrm{O}$ Project & NWS & National Weather Service \\
\hline INX & Tulsa, Oklahoma & OKC & Oklahoma City, Oklahoma \\
\hline IOP & intensive observing period & OU & University of Oklahoma \\
\hline IOR & intensive operation region & OUN & Norman, Oklahoma \\
\hline ISFF & Integrated Surface Flux Facility & PI & principal investigator \\
\hline ISS & Integrated Sounding System & PUX & Pueblo, Colorado \\
\hline JOSS & Joint Office for Science Support & QPF & quantitative precipitation forecasting \\
\hline $\mathrm{KF}$ & Kain-Fritsch & RASS & radio acoustic sounding system \\
\hline $\mathrm{L} 2$ & Leandre II water vapor DIAL & REU & Research Education for Undergraduate \\
\hline LAPS & Local Analysis and Prediction System & RUC & Rapid Update Cycle \\
\hline LASE & Lidar Atmospheric Sensing & SGF & Springfield, Missouri \\
\hline & Experiment & SGP & Southern Great Plains \\
\hline LBF & North Platte, Nebraska & S-HIS & Scanning High-Resolution \\
\hline LLJ & low-level jet & & Interferometer Sounder \\
\hline
\end{tabular}


SHV

SMART-R Shared Mobile Atmospheric Research and Teaching Radar

SPC

S-Pol

SRL

TAMU

TAOS

TOP

TPW

UA

UConn

UEX

UMass

USAF

USWRP

UTC

UWKA

VNX

WCR

WRF

WSR-88D

X-Pol

Storm Prediction Center

S-band dual-polarization Doppler radar

scanning Raman lidar

Texas A\&M University

Tethered Atmospheric Observing

System

Topeka, Kansas

total precipitable water

University of Alabama

University of Connecticut

Hastings, Nebraska

University of Massachusetts

United States Air Force

United States Weather Research

Project

coordinated universal time

University of Wyoming King Air

Vance AFB, Oklahoma

Wyoming Cloud Radar

Weather Research and Forecasting model

Weather Surveillance Radar-1988

Doppler

Mobile X-Band Polarimetric Radar

\section{REFERENCES}

Abdul, J. A., 1955: The atmospheric solitary wave. Bull. Amer. Meteor. Soc., 36, 511-518.

Anthes, R. A., Y.-H. Kuo, S. G. Benjamin, and Y.-F. Li, 1982: The evolution of the mesoscale environment of severe local storms: Preliminary modeling results. Mon. Wea. Rev., 110, 1187-1213.

Avissar, R., and T. Schmidt, 1998: An evaluation of the scale at which ground-surface heat flux patchiness affects the convective boundary layer using largeeddy simulations. J. Atmos. Sci., 55, 2666-2689.

Basara, J. B., and K. C. Crawford, 2002: Linear relationships between root-zone soil moisture and atmospheric processes in the planetary boundary layer. $J$. Geophys. Res., 107 (D15), 1-18.

Beljaars, A. C., P. Vitterbo, M. J. Miller, and A. K. Betts, 1995: The anomalous rainfall over the USA during July 1993: Sensitivity to land surface parameterization and soil moisture anomalies. ECMWF Tech. Memo. 214, ECMWF, Shinfield Park, Reading, United Kingdom, 34 pp.

Bell, R. S., and O. Hammon, 1989: The sensitivity of fine-mesh rainfall and cloud forecasts to the initial specification of humidity. Meteor. Mag., 118, $152-$ 158.

Biggerstaff, M. I., and J. Guynes, 2000: A new tool for atmospheric research. Preprints, 20th Conf. on Severe Local Storms, Orlando, FL, Amer. Meteor. Soc., 277280.

Bluestein, H. B., 1993: CLASS for class. Bull. Amer. Meteor. Soc., 74, 1697-1702.

— , and A. L. Pazmany, 2000: Observations of tornadoes and other convective phenomena with a mobile, $3-\mathrm{mm}$ wavelength, Doppler radar: The spring 1999 field experiment. Bull. Amer. Meteor. Soc., 81, 2939-2951.

Browell, E. V., and Coauthors, 1997: LAS E validation experiment. Advances in Atmospheric Remote Sensing with Lidar, A. Ansmann, R. Neuber, P. Rairoux, and U. Wandinger, Eds., Springer Verlag, 289-295.

Bruneau, D., P. Quaglia, C. Flamant, M. Meissonnier, and J. Pelon, 2001: Airborne lidar LEANDRE II for water-vapor profiling in the troposphere. Appl. Opt., 40, 3450-3475.

Businger, S., and Coauthors, 1996: The promise of GPS in atmospheric monitoring. Bull. Amer. Meteor. Soc., 77, 5-18.

Carbone, R. E., J. W. Conway, N. A. Crook, and M. W. Moncrieff, 1990: The generation and propagation of a nocturnal squall line. Part I: Observations and implications for mesoscale predictability. Mon. Wea. Rev., 118, 26-49.

Chen, F., and R. Avissar, 1994: The impact of land-surface wetness heterogeneity on mesoscale heat fluxes. J. Appl. Meteor., 33, 1323-1340.

—, K. Mitchell, Z. Janjic, and M. Baldwin, 1998: Impact of land-surface processes on the NCEP Eta Model quantitative precipitation forecast. Preprints, Special Symp. on Hydrology, Phoenix, AZ, Amer. Meteor. Soc., 281-282.

—, M. A. LeMone, D. N. Yates, R. L. Grossman, R. Cuenca, T. Horst, D. Niyogi, and P. Blanken, 2003: Utilizing the IHOP 2002 data to study the variability in surface evaporation and water vapor in the boundary layer. Preprints, Symp. on Observing and Understanding the Variability of Water in Weather and Climate, Long Beach, CA, Amer. Meteor. Soc., AMS 2003 Annual Meeting CD-ROM, P1.2.

Christie, D. R., K. J. Muirhead, and A. L. Hales, 1979: Intrusive density flows in the lower troposphere: A source of atmospheric solitons. J. Geophys. Res., 84, 4959-4970.

Cohn, S. A., W. O. J. Brown, C. L. Martin, M. E. Susedik, G. Maclean, and D. B. Parsons, 2001: Clear air boundary layer spaced antenna wind measurement with the Multiple Antenna Profiler (MAPR). Ann. Geophys., 19, 845-854. 
Crook, N. A., 1996: Sensitivity of moist convection forced by boundary layer processes to low-level thermodynamic fields. Mon. Wea. Rev., 124, 17671785.

Dabberdt, W. F., and T. W. Schlatter, 1996: Research opportunities from emerging atmospheric observing and modeling capabilities. Bull. Amer. Meteor. Soc., 77, 305-323.

Dodson, A., W. Chen, N. T. Penna, and H. Baker, 2001: GPS estimation of atmospheric water vapour from a moving platform. J. Atmos. Sol.-Terr. Phys., 63, 13311341.

Doswell, C. A., III, H. E. Brooks, and R. A. Maddox, 1996: Flash flood forecasting: An ingredients-based methodology. Wea. Forecasting, 11, 560-581.

Doviak, R. J., and R. Ge, 1984: An atmospheric solitary gust observed with a Doppler radar, a tall tower, and a surface network. J. Atmos. Sci., 41, 2559-2573.

—, S. S. Chen, and D. R. Christie, 1991: A thunderstorm-generated solitary wave observation compared with theory for nonlinear waves in a sheared atmosphere. J. Atmos. Sci., 48, 87-111.

Droegemeier, K. K., and Coauthors, 2002: Project CRAFT: A test bed for demonstrating the real time acquisition and archival of WSR-88D level II data. Preprints, 18th Int. Conf. on Interactive Information Processing Systems (IIPS) for Meteorology, Oceanography, and Hydrology, Orlando, FL, Amer. Meteor. Soc., 136-139.

Ebert, E. E., and J. L. McBride, 2000: Verification of precipitation in weather systems: Determination of systematic errors. J. Hydrol., 3, 179-202.

Emanuel, K., and Coauthors, 1995: Report of first prospectus development team of the U.S. weather research program to NOAA and the NSF. Bull. Amer. Meteor. Soc., 76, 1194-1208.

Fabry, F., C. Frush, I. Zawadzki, and A. Kilambi, 1997: On the extraction of near-surface index of refraction using radar phase measurements from ground targets. J. Atmos. Oceanic Technol., 14, 978-987.

Feltz, W. F., H. B. Howell, R. O. Knuteson, H. M. Woolf, and H. E. Revercomb, 2003: Near-continuous profiling of temperature, moisture, and atmospheric stability using the Atmospheric Emitted Radiance Interferometer (AERI). J. Appl. Meteor., 42, 584597.

Frederickson, S. E., 1993: National Severe Storms Laboratory mobile atmospheric observatories; Surface meteorological measurements. Preprints, Eighth Symp. on Meteorological Observations and Instrumentation, Anaheim, CA, Amer. Meteor. Soc., 219-224.

Fulton, R., D. S. Zrnic, and R. J. Doviak, 1990: Initiation of a solitary wave family in the demise of a noctur- nal thunderstorm density current. J. Atmos. Sci., 47, 319-337.

Gentry, B. M., H. Chen, and S. X. Li, 2000: Wind measurements with a $355 \mathrm{~nm}$ molecular Doppler lidar. Opt. Lett., 25, 1231-1233.

Golden, J. H., R. Serafin, V. Lally, and J. Facundo, 1986: Atmospheric sounding systems. Mesoscale Meteorology and Forecasting, P. S. Ray, Ed., Amer. Meteor. Soc., 50-70.

Grund, C. J., R. M. Banta, J. L. George, J. N. Howell, M. J. Post, R. A. Richter, and A. M. Weickmann, 2001: High-resolution Doppler lidar for boundary layer and cloud research. J. Atmos. Oceanic Technol., 18, 376-393.

Guichard, F., D. Parsons, and E. Miller, 2000: Thermodynamic and radiative impact of the correction of sounding humidity bias in the tropics. J. Climate, 13, 3611-3624.

Hildebrand, P. H., and Coauthors, 1996: The ELDORA/ ASTRAIA airborne Doppler weather radar: Highresolution observations for TOGA COARE. Bull. Amer. Meteor. Soc., 77, 213-232.

Hock, T. F., and J. L. Franklin, 1999: The NCAR GPS dropwindsonde. Bull. Amer. Meteor. Soc., 80, 407-420.

Huggins, A. W., 1995: Mobile microwave radiometer observations: Spatial characteristics of supercooled cloud water and cloud seeding implications. J. Appl. Meteor., 34, 432-446.

Ince, T., S. J. Frasier, A. Muschinski, and A. L. Pazmany, 2003: AM S-band frequency modulated continuous wave boundary layer profiler: Description and initial results. Radio Sci., 38 (4), 1072, doi: 10/ 2002RS002753.

Janish, P. R., S. J. Weiss, R. Schnieder, and P. Bothwell, cited 2002: Spring Program 2002: Program overview and operations plan. [Available online at http:// www.spc.noaa.gov/exper/Spring_2002/2002opsw. htm.]

Karyampudi, V. M., S. E. Koch, C. Chen, J. W. Rottman, and M. L. Kaplan, 1995: The influence of the Rocky Mountains on the 13-14 April 1986 severe weather outbreak. Part II: Evolution of a prefrontal bore and its role in triggering a squall line. Mon. Wea. Rev., 123, 1423-1446.

Knupp, K. R., J. Walters, and E. W. McCaul Jr., 2000: Doppler profiler observations of Hurricane Georges at landfall. Geophys. Res. Lett., 27, 3361-3364.

Koch, S. E., and W. L. Clark, 1999: A nonclassical cold front observed during COPS-91: Frontal structure and the process of severe storm initiation. J. Atmos. Sci., 56, 2862-2890.

_ , P. B. Dorian, R. Ferrare, S. H. Melfi, W. C. Skillman, and D. Whiteman, 1991: Structure of an internal bore 
and dissipating gravity current as revealed by Raman lidar. Mon. Wea. Rev., 119, 857-887.

—, A. Aksakal, and J. T. McQueen, 1997: The influence of mesoscale humidity and evapotranspiration fields on a model forecast of a cold-frontal squall line. Mon. Wea. Rev., 125, 384-409.

—, F. Zhang, M. L. Kaplan, Y.-L. Lin, R. Weglarz, and C. M. Trexler, 2001: Numerical simulations of a gravity wave event over CCOPE. Part III: The role of a mountain-plains solenoid in the generation of the second wave episode. Mon. Wea. Rev., 129, 909-933.

Lesht, B. M., 1995: An evaluation of ARM radiosonde operational performance. Proc. Ninth Symp. on $\mathrm{Me}$ teorological Observations and Instrumentation, Charlotte, NC, Amer. Meteor. Soc., 6-10.

Locatelli, J. D., M. T. Stoelinga, and P. V. Hobbs, 2002: A new look at the super outbreak of tornadoes on 34 April 1974. Mon. Wea. Rev., 130, 1633-1651.

Lutz, J., P. Johnson, B. Lewis, E. Loew, M. Randall, and J. VanAndel, 1995: NCAR's S-Pol: Portable polarimetric S-band radar. Preprints, Ninth Symp. on Meteorological Observations and Instrumentation, Charlotte, NC, Amer. Meteor. Soc., 408-410.

Machol, J. L., and Coauthors, 2004: Preliminary measurements with an automated compact differential absorption lidar for profiling water vapor. Appl. Opt., in press.

Mahapatra, P. R., R. J. Doviak, and D. S. Zrnic, 1991: Multisensor observation of an atmospheric undular bore. Bull. Amer. Meteor. Soc., 72, 1468-1480.

Mailhot, J., C. Chouinard, R. Benoit, M. Roch, G. Verner, J. Coté, and J. Pudykiewicz, 1989: Numerical forecasting of winter coastal storms during CASP: Evaluation of the regional finite-element model. Atmos.Ocean, 27, 24-58.

Menhofer, A., R. K. Smith, M. J. Reeder, and D. R. Christie, 1997: "Morning-glory" disturbances and the environment in which they propagate. J. Atmos. Sci., 54, 1712-1725.

Mills, G. A., 1983: The sensitivity of a numerical prognosis to moisture detail in the initial state. Aust. Meteor. Mag., 31, 111-119.

—, and N. E. Davidson, 1987: Tropospheric moisture profiles from digital IR satellite imagery: System description and analysis/forecast impact. Aust. Meteor. Mag., 35, 109-118.

Montmerle, T., A. Caya, and I. Zawadzki, 2002: Shortterm numerical forecasting of a shallow storms complex using bistatic and single-Doppler radar data. Wea. Forecasting, 17, 1211-1225.

National Research Council, 1998: The Atmospheric Sciences: Entering the Twenty-first Century. National Academy Press, 364 pp.
Parsons, D., and Coauthors, 1994: The integrated sounding system: Description and preliminary observations from TOGA COARE. Bull. Amer. Meteor. Soc., 75, 553-568.

—, M. A. Shapiro, and E. Miller, 2000: The mesoscale structure of nocturnal dryline and of a frontaldryline merger. Mon. Wea. Rev., 128, 3824-3838.

Pazmany, A., R. McIntosh, R. Kelly, and G. Vali, 1994: An airborne $95 \mathrm{GHz}$ dual-polarized radar for cloud studies. IEEE Trans. Geosci. Remote Sens., 32, 731739.

Perkey, D. J., 1976: A description and preliminary results from a fine-mesh model for forecasting quantitative precipitation. Mon. Wea. Rev., 104, 1513-1526.

Poberaj, G., A. Fix, A. Assion, M. Wirth, C. Kiemle, and G. Ehret, 2002: Airborne all-solid-state DIAL for water vapour measurements in the tropopause region: System description and assessment of accuracy. Appl. Phys., B75, 165-172.

Revercomb, H. E., and Coauthors, 1998: Recent results from two new aircraft-based Fourier-transform interferometers: The scanning high-resolution interferometer sounder and the NPOESS atmospheric sounder testbed interferometer. Proc. 8th Int. Workshop on Atmospheric Science from Space using Fourier Transform Spectrometry (ASSFTS), Toulouse, France, 16-18

- , and Coauthors, 2003: The Atmospheric Radiation Measurement (ARM) Program's water vapor intensive operational periods: Overview, accomplishments, and future challenges. Bull. Amer. Meteor. Soc., 84, 217-236.

Schwemmer, G., T. Wilkerson, and D. Guerra, 1998: Compact scanning lidar systems using holographic optics. Proc. SPIE Vol. 3504, Optical Remote Sensing for Industry and Environmental Monitoring, SPIE, 51-59. [Available online at http://deluge.ssec.wisc. edu/ shis/.]

Segal, M., and R. W. Arritt, 1992: Nonclassical mesoscale circulations caused by sensible heat-flux gradients. Bull. Amer. Meteor. Soc., 73, 1593-1604.

Shreffler, J. H., and F. S. Binkowski, 1981: Observations of pressure jump lines in the Midwest, 10-12 August 1976. Mon. Wea. Rev., 109, 1713-1725.

Skyllingstad, E. D., 1991: Critical layer effects on atmospheric solitary and cnoidal waves. J. Atmos. Sci., 48, 1613-1624.

Soden, B., and J. Lanzante, 1996: An assessment of satellite and radiosonde climatologies of upper-tropospheric water vapor. J. Climate, 9, 1235-1250.

Straka, J. M., E. N. Rasmussen, and S. E. Fredrickson, 1996: A mobile mesonet for finescale meteorological observations. J. Atmos. Oceanic Technol., 13, 921-936. 
Tepper, M., 1950: A proposed mechanism of squall lines-The pressure jump line. J. Meteor., 7, 21-29.

Turner, D. D., B. M. Lesht, S. A. Clough, J. C. Liljegren, H. E. Revercomb, and D. C. Tobin, 2003: Dry bias and variability in Vaisala RS80-H radiosondes: The ARM experience. J. Atmos. Oceanic Technol., 20, $117-132$.

Uccellini, L. W., P. J. Kocin, and J. M. Sienkiewicz, 1999: Advances in forecasting extratropical cyclogenesis at the National Meteorological Center. The lifecycles of extratropical cyclones, M. A. Shapiro and S. Grønås, Eds., AMS, 317-336.

Wang, J., H. L. Cole, D. J. Carlson, E. R. Miller, K. Beierle, A. Paukkunen, and T. K. Laine, 2002: Corrections of humidity measurement errors from the Vaisala RS80 radiosonde-Application to TOGA COARE data. J. Atmos. Oceanic Technol., 19, 9811002.

—, D. J. Carlson, D. B. Parsons, T. F. Hock, D. Lauritsen, H. L. Cole, K. Beierle, and E. Chamberlain, 2003: Performance of operational radiosonde humidity sensors in direct comparison with a chilled mirror dew-point hygrometer and its climate implication. Geophys. Res. Lett., 30, 1860, doi: 10.1029/2003GL016985.

Weckwerth, T. M., 2000: The effect of small-scale moisture variability on thunderstorm initiation. Mon. Wea. Rev., 128, 4017-4030.
—, J. W. Wilson, and R. M. Wakimoto, 1996: Thermodynamic variability within the convective boundary layer due to horizontal convective rolls. Mon. Wea. Rev., 124, 769-784.

—, V. Wulfmeyer, R. M. Wakimoto, R. M. Hardesty, J. W. Wilson, and R. M. Banta, 1999: NCAR-NOAA lower-tropospheric water vapor workshop. Bull. Amer. Meteor. Soc., 80, 2339-2357.

Whiteman, D. N., and S. H. Melfi, 1999: Cloud liquid water, mean droplet radius and number density measurements using a Raman lidar. J. Geophys. Res., 104, 31 411-31419.

- , and Coauthors, 2001: Raman lidar measurements of water vapor and cirrus clouds during the passage of hurricane Bonnie. J. Geophys. Res., 106, 52115225.

Wilson, J. W., and W. E. Schreiber, 1986: Initiation of convective storms at radar-observed boundary-layer convergence lines. Mon. Wea. Rev., 114, 2516-2536.

$\longrightarrow$, N. A. Crook, C. K. Mueller, J. Sun, and M. Dixon, 1998: Nowcasting thunderstorms: A status report. Bull. Amer. Meteor. Soc., 79, 2079-2100.

Wurman, J., 2001: The DOW mobile multiple-Doppler network. Preprints, 30th Int. Conf. on Radar Meteorology, Munich, Germany, Amer. Meteor. Soc., 95-97.

Zhou, D. K., and Coauthors, 2002: Thermodynamic product retrieval methodology and validation for NAST-I. Appl. Opt., 41, 6957-6967.

\section{Call for Weather-Related Art and Photos}

The Bulletin of the American Meteorological Society invites submission of original, weather-related art and photos for potential publication in future issues of the magazine. The Bulletin staff is especially interested in work that is artistic and creative, featuring a unique, interesting perspective; chosen works will be used to help add more graphic appeal to the Bulletin. Specific use of the images will be determined by the production staff. Please be aware that your submission will not be peer reviewed-we will be looking at submissions more from an aesthetic viewpoint than a scientific one. (Photos intended for scientific publication should be submitted following normal Bulletin guidelines for peer-reviewed submissions.) Nonetheless, all submissions will be given equal consideration.

We hope that you will take this ongoing opportunity to inspire your colleagues and shape the look of your Society's publication. Ownership of the works will be retained by the artist/photographer; we do not offer payment for published submissions.

Submission requirements: For artwork, please do not submit the original work of art-send only a high-quality color photo of the piece. For art and all other photographs submitted for consideration, send only first-quality, camera-ready prints or slides (no photocopies, please). Submissions will not be returned unless accompanied by a self-addressed envelope with correct postage.

Please include with the submission your name, the title of the work (if applicable), and any other relevant information. If a description of the submission would be helpful, please include a succinct caption.

Please submit your work to: David Gershman, Manager of Art and Design, AMS, 45 Beacon St., Boston, MA 02108-3693. 


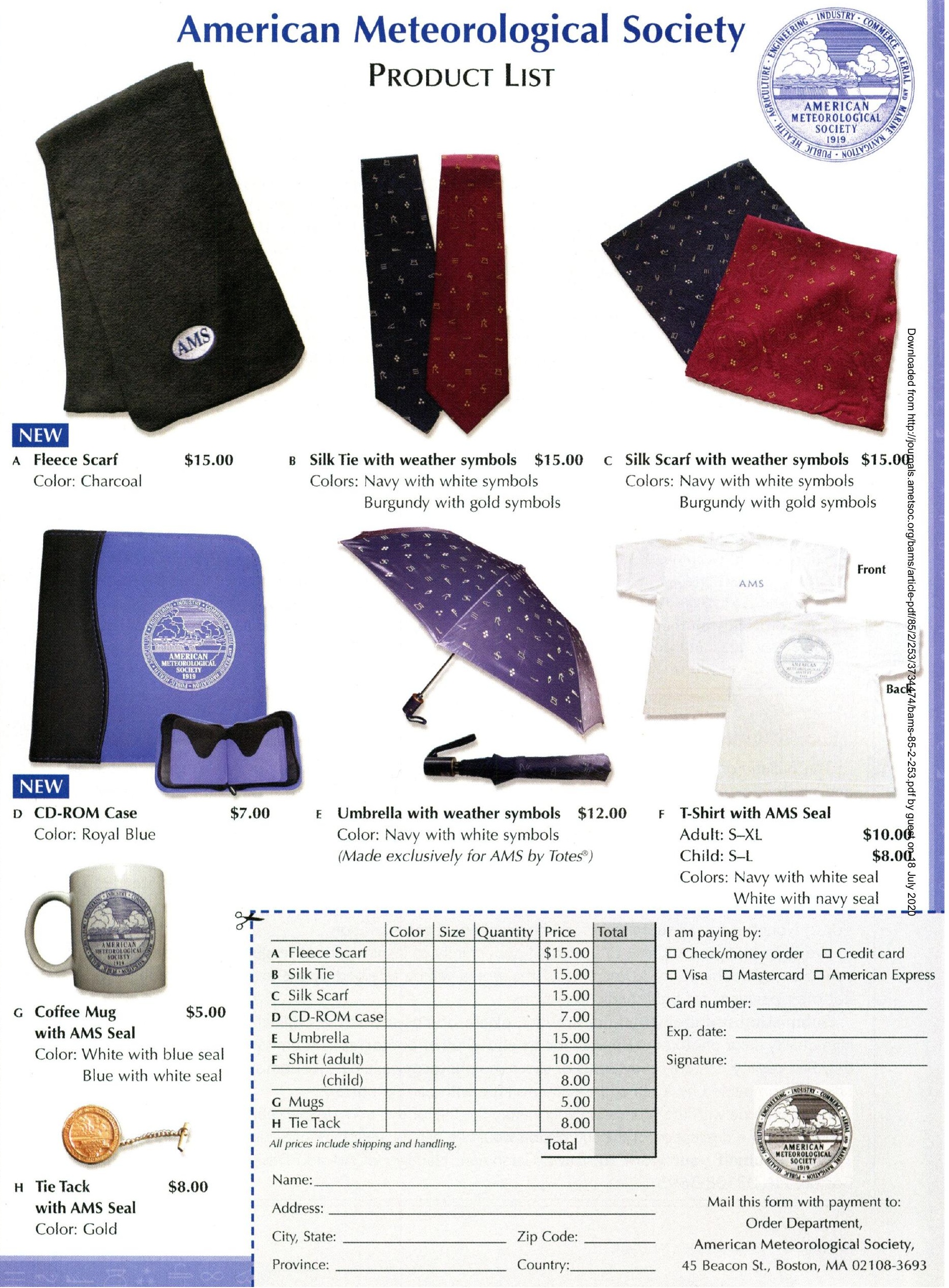

